\title{
Novelties and records of poroid Basidiomycetes in Finland and adjacent Russia
}

\author{
TUOMO NIEMELÄ, JUHA KINNUNEN, MARIKO LINDGREN, OLLI MANNINEN, \\ OTTO MIETTINEN, REIJO PENTTILÄ and OLLI TURUNEN
}

NIEMELÄ, T., KINNUNEN, J., LINDGREN, M., MANNINEN, O., MIETTINEN, O., PENTTILÄ, R. \& TURUNEN, O. 2001: Novelties and records of poroid Basidiomycetes in Finland and adjacent Russia. - Karstenia 41: 00-00. Helsinki. ISSN 04533402 .

Postia alni Niemelä \& Vampola, spec. nova (Basidiomycetes, Aphyllophorales), is a narrow-spored relative of Postia caesia (Schrad. : Fr.) P. Karst., growing on broadleaved trees, e.g., alder and aspen. Skeletocutis friata Niemelä \& Saarenoksa, nom. novum, will replace $S$. friabilis Niemelä \& Saarenoksa, a homonym of $S$. friabilis (Corner) Quanten. The following combinations are proposed: Fibroporia norrlandica (Berglund \& Ryvarden) Niemelä, comb. nova (Oligoporus norrlandicus Berglund \& Ryvarden); Junghuhnia lacera (P. Karst.) Niemelä \& Kinnunen, comb. nova (J. separabilima (Pouzar) Ryvarden). The following polypores are reported as new to Finland: F. norrlandica (also reported from France), Sistotrema dennisii Malençon, Skeletocutis ochroalba Niemelä, and Postia mappa (Overh. \& Lowe) M.J. Larsen \& Lombard. Skeletocutis krawtzewii (Pilát) Kotl. \& Pouzar is reported from eastern Leningrad Region, Russia; this is the second find of the species after its description from Siberia. Junghuhnia fimbriatella (Peck) Ryvarden was found in Leningrad Region; this is the first record in northern Europe. Skeletocutis borealis Niemelä and many other rare species are discussed, including new localities from Finland and/or NW Russia. Some of them are illustrated, and many species are supplied with detailed spore measurements. 143 polypore species were recorded and collected by the authors and their co-workers in virgin forests of Russian Karelia in wide sense; 12 of them are new to the area.

Key words: Aphyllophorales, Basidiomycetes, Finland, fungi, Karelia, old-growth forest, polypores, Russia

Tuomo Niemelä, Juha Kinnunen, Botanical Museum, Mycology Division, P.O. Box 47, FIN-00014 University of Helsinki, Finland

Mariko Lindgren, Olli Manninen, Otto Miettinen, Olli Turunen, Department of Ecology and Systematics, Division of Systematic Biology, P.O. Box 47, FIN-00014 University of Helsinki, Finland

Reijo Penttilä, Kainuu Regional Environment Centre, Research Centre of Friendship Park, Tönölä, FIN-88900 Kuhmo, Finland

\section{Introduction}

The polypore species composition of the boreal coniferous forests of Northwest Europe is well known - the area evidently belongs to the beststudied areas in the world as regards its wood- inhabiting fungi. However, even there new species are found almost annually. One reason is that large areas of northern taiga are still in a pristine state, unlike virtually all the forests of 
Central and South Europe. The northern oldgrowth forests have been intensively inventoried during recent years, in particular in Norway, Sweden and Finland, but also in parts of Russia.

Hot-spot inventories have been carried out by Finnish students in several areas of adjacent NW Russia, for instance with the support of the Finnish Nature League (e.g. Pyykkö 1996, Ovaskainen 1998). Rather little has been published on recent finds from Russian Karelia and adjacent areas, however, and therefore we here list the species recorded by the authors during fieldwork in 1994-2000.

Shubin and Krutov (1979) published the first checklist of fungi of the Karelian Republic. See also the brief history of mycological exploration of Karelian Republic by Krutov (1998). An early paper by Laurila (1939) includes noteworthy records from the provinces $\mathrm{Kl}$ and $\mathrm{Ks}$ (see Fig. 2). In the 1990s especially Lositskaya $(1997,1998)$ has studied the Karelian wood-rotting fungi. Bondartseva et al. (2000) have published an extensive list of the Aphyllophorales of the area. Freyndling (1949), Bondartseva and Svishch (1993) and Bondartseva et al. (1995) include inventories of the polypores in the Kivach Nature Reserve (province Kon). Thereafter Lindgren (2001) published a thorough account of the polypores and their ecology in the Kostomuksha and Kalevala Districts (province Kpoc), and Siitonen et al. (2001) included polypores in their major

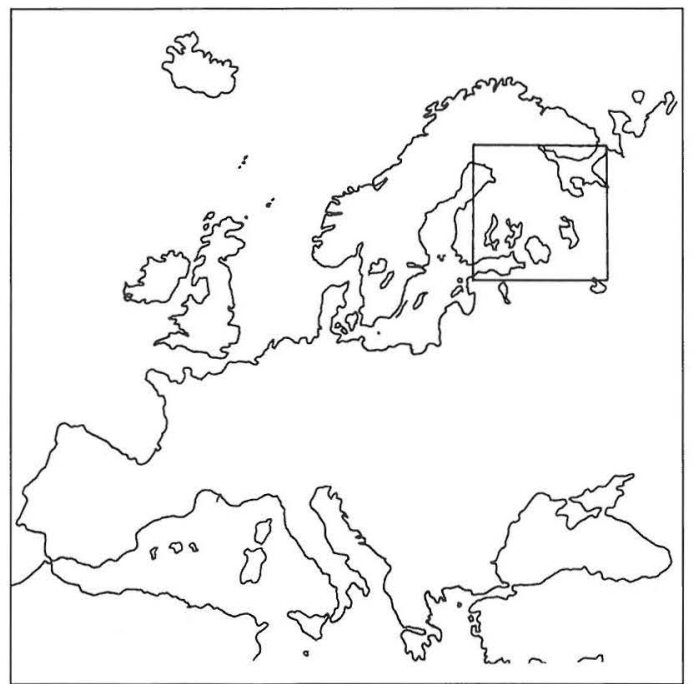

Fig. 1. Study area in northwestern Europe (square). study on old-growth forest organisms in Vodlozero National Park in Pudozh District.

The Aphyllophorales of the Leningrad Region were recently listed by Bondartseva et al. (1999). An earlier list of polypores of the Leningrad Region was published by Bondartseva (1964). Her recent (Bondartseva 1998) comprehensive survey of Russian polypores also lists many species from our study area. Zmitrovich (1999a, b) has listed the Aphyllophorales fungi in the Nizhniy Svir Reserve, east shore of Lake Ladoga, and in Leningrad Region. Noskov (2000) treated the threatened species of the Leningrad Region. An early list by Thesleff (1920) primarily treats the fungus flora around the town of Vyborg (province $\mathrm{Ka}$ ), but his identifications are not always reliable. Working in St. Petersburg (Leningrad), Bondartsev (1953) could give plenty of records on the species of the area. Lositskaya (1997) surveyed the Aphyllophorales of the Valaam Islands, Lake Ladoga.

One of our study areas, viz. the Onega Peninsula, belongs to the western Archangel Region. No earlier records of polypores are known to us from that area.

\section{Materials and methods}

The following name abbreviations of the authors are used: JK (Juha Kinnunen), ML (Mariko Lindgren), OMA (Olli Manninen), OMI (Otto Miettinen), TN (Tuomo Niemelä), RP (Reijo Penttilä) and OT (Olli Turunen).

A list of polypores found in certain areas of oldgrowth forests in NW Russia was prepared by ML, OMA, OMI, OT and RP based on their own collections and field observations. Earlier records in the literature (which contain many unconfirmed old identifications), as well as possible earlier herbarium specimens were omitted. The first set of the collections is preserved, or will be deposited in Herb. H (Helsinki). As to Finland, the Karelian Republic, and the northern Leningrad Region in Russia, the biogeographical provinces cited are those recognized in Kotiranta et al. (1998); abbreviations of the Russian provinces are also shown on a map in Kravchenko et al. (2000: 6). The study area is shown on Fig. 1, and its subdivision into biogeographical provinces on Fig. 2.

Our main study areas in NW Russia, the field workers, and the periods of fieldwork are:

Leningrad Region, Vyborg Dist. (prov. Ik and Ka): August 1993 (OT), October 1997 (OT), May 1998 (ML), September 1998 (OT); Svetogorsk, August 1998 (ML).

Leningrad Region, Tikhvin Dist.: Veps Forest Reserve, May-June 2000 (Jenni Hottola, OMA, OMI).

Karelian Republic, Lakhdenpokh'ya and Pitkyaranta Dist. (prov. Kl): June 1998 (OT), July 1999 (OT), June 2000 (OT). 
Karelian Republic, Pryazha, Prionezhskiy and Olonets Dist. (prov. Kol): August 1993 (OT), June 1998 (OT).

Karelian Republic, Suoyarvi Dist. (prov. Kb): June 1998 (OT), July 1999 (OT).

Karelian Republic, Kondopoga Dist. (prov. Kon): Kivach Nature Reserve, August 1993 (OT), May 1997 (ML, OMI, OT), August 1997 (RP).

Karelian Republic, Pudozh Dist. (prov. Kton): August 2000 (OT), Vodlozero National Park, August-September 1994 (RP).

Karelian Republic, Muezero Dist. (prov. Kpoc): April, July 2000 (OT), planned Tulos National Park, September 2000 (Jenni Hottola).

Karelian Republic, Muezero Dist. (prov. Kpoc): forests SE of the Kostomuksha Strict Nature Reserve, July and September 1995 (ML).

Karelian Republic, Kalevala Dist. (prov. Kpoc): planned Kalevala National Park, July-September 1995 (ML), July-September 1996 (ML), August-September 1998 (ML), September 1999 (ML, OMA).

Karelian Republic, Belomorsk and Zegezha Dist. (prov. Kpor): August 1999 (OT).

Karelian Republic, Loukhi and Kem' Dist. (prov. Kk): September 1999 (OT).

Archangel Region, Onega Dist.: Onega Peninsula, June-July 1999 (ML, OMA).

The final discussion on the conservation value and characteristics of NW Russian old forests is based on the notes, ideas and field experiences by ML and RP.

In species descriptions the following abbreviations are used. Cotton Blue (CB), Melzer's reagent (IKI) and 5\% potassium hydroxide $(\mathrm{KOH})$ are the media for making microscopic mounts. Their exact compositions are as defined in Niemelä (1985a). In presenting the variation of spore size, $5 \%$ of the measurements out of each end of the range are given in parentheses. $\mathrm{L}=$ mean length (arithmetical mean of all spores), $\mathrm{W}=$ mean width, $\mathrm{Q}=$ length/width ratio, and $\mathrm{n}=$ the number of spores measured from given number of specimens. Measurements were made in $\mathrm{CB}$ and drawings were made from slides mounted in that medium.

In the lists of specimens only those are cited that were included in spore measurements, or were otherwise more thoroughly studied and referred to in the text.

\section{Species discussions}

\section{Antrodia sitchensis (D.V. Baxter) Gilb. \& Ryvarden}

The rare Antrodia sitchensis was collected in three places in the Veps Forest (for the area, see Popova \& Noskov 1999), $300 \mathrm{~km}$ east of St. Petersburg. All the finds are from fallen trunks of spruce, $17-45 \mathrm{~cm}$ in diameter, growing in moist, old spruce forests. New NW Russian records are also given from the Karelian Isthmus, Kivach and Kostomuksha (Tab. 1). Previously Siitonen et al. (2001) reported the species from the Vodlozero National Park (province Kton), and we also col-

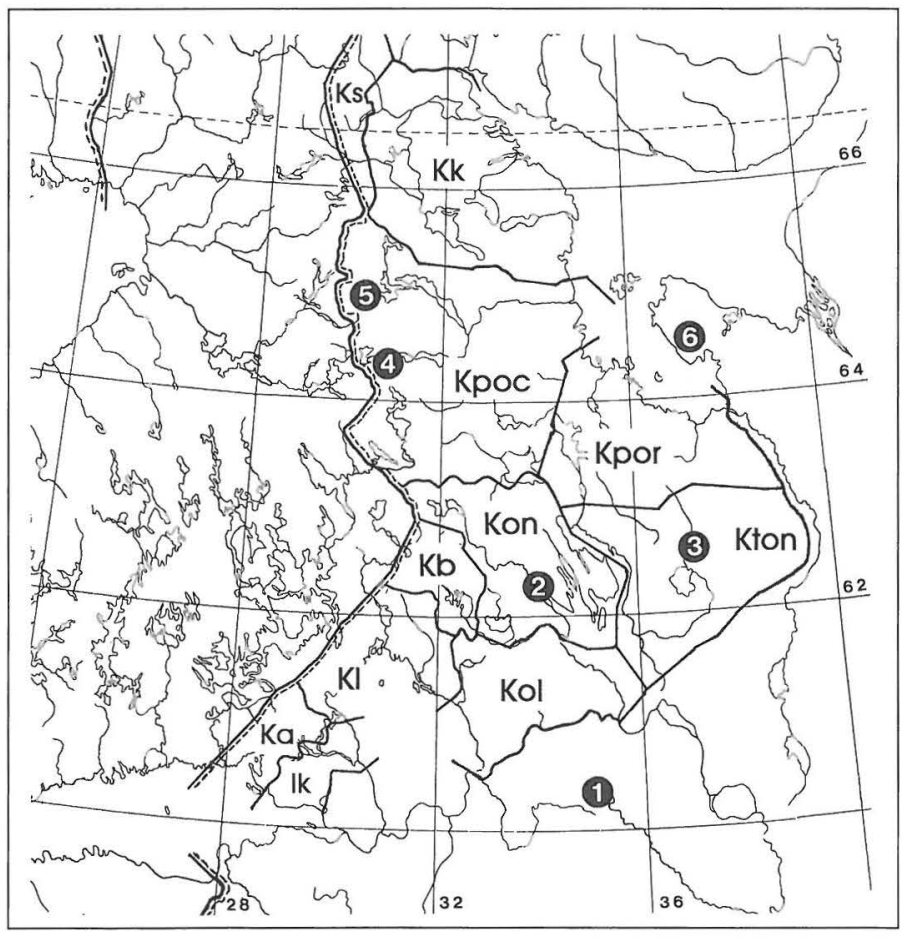

Fig. 2. Biogeographical provinces of Russian Fennoscandia; abbreviations according to Kotiranta et al. (1998) and Kravchenko et al. (2000); nos. 1 and 6 lie outside Fennoscandia. Located are some areas in which intensive inventories were carried out: (1) Veps Forest, (2) Kivach Reserve, (3) Vodlozero Park, (4) forests SE of Kostomuksha Reserve, (5) planned Kalevala National Park, (6) Onega Peninsula. 
lected it there. Antrodia sitchensis is very rare in Europe, occurring in Finland, Norway, Estonia, the Czech Republic, Poland, Ukraine and Croatia.

The spores of $A$. sitchensis are cylindric, (3.5) $3.9-5.1(-5.4) \times(1.6-) 1.8-2.3(-2.6) \mu \mathrm{m}, \mathrm{L}=4.48 \mu \mathrm{m}$, $\mathrm{W}=2.00 \mu \mathrm{m}, \mathrm{Q}=2.06-2.47(\mathrm{n}=150 / 5$; dimensions from the below-listed specimens).

Specimens examined: Finland. Etelä-Häme: Padasjoki, Vesijako Strict Nature Reserve, Picea abies, 15.IX.1994 Niemelä 5833, 3.VIII.1996 Niemelä 6023, 7.XI.1996 Niemelä 6077 (H). Canada. British Columbia: Vancouver Island, Lake Cowichan Prov. Forest, Pseudotsuga menziesii, 6.IX.1967 Eriksson 7555 (GB). Russia. Leningrad Region: Tikhvin Dist., Veps Forest, Picea abies, 26.V.2000 Manninen 628, 2.VI.2000 Manninen 803, 5.VI.2000 Miettinen $2141(\mathrm{H})$. Primorye Terr., Bulyga-Fadeevo, Picea jezoensis, 6.IX.1975 Parmasto (TAA 59287).

\section{Antrodia sordida Ryvarden \& Gilb.}

Originally described from North America (as Poria oleagina Overh., nom. inval.), Antrodia sord$i d a$ has been reported only a few times in Europe (Ryvarden \& Gilbertson 1993). In our material there are two NW Russian specimens referred to that species. Unfortunately only one of them (Lindgren 582a) is fertile with cylindric spores, (4.4-)4.8-6(-6.1) $\times(1.6-) 1.7-1.9(-2) \mu \mathrm{m}, \mathrm{L}=5.34$ $\mu \mathrm{m}, \mathrm{W}=1.82 \mu \mathrm{m}, \mathrm{Q}=2.93(\mathrm{n}=30 / 1)$. The species reminds Antrodia sitchensis, but is more brittle when dry, while the latter is woody hard. The reason is different hyphal structure. Tramal skeletals are tightly interwoven in $A$. sitchensis (Niemelä et al. 1992), but spaced and subparallel in $A$. sordida. The spores of $A$. sitchensis are shorter but wider than those of this species. The identity and characteristics of $A$. sordida would deserve a closer study. New to Russia.

Specimens examined: Russia. Leningrad Region: Tikhvin Dist., Veps Forest, Picea abies, 28.V.2000 Miettinen $141(\mathrm{H})$. Karelian Republic: Muezero Dist., the planned Kalevala National Park, Venehlampi $2 \mathrm{~km}$ NW, Picea abies, 15.IX.1998 Lindgren 52/62a (H). Germany. Sachsen: Kreis Niesky, Pinus sylvestris, 24.IX.1985 Stark 14867 (O).

\section{Diplomitoporus flavescens (Bres.) Domański}

Diplomitoporus flavescens is rare in South Finland, and has recently been found in Finnish Lapland. Hermansson (1997) reported it from the Komi Republic, and Bondartseva (1998) from seven areas of European Russia, e.g., Leningrad
Region. We found it in the Veps Forest, Karelian Isthmus and Vodlozero. Most habitats were dry, exposed and sunny, for instance lakesides or fairly thin stands of young pine. In Vodlozero the species occurred on fallen pine in a small windfall opening of a spruce-dominated, mesic forest. More typically (for instance in Central Europe, also South Finland) the species grows on standing, dwarf-size pines in peatlands.

The spores of $D$. flavescens are wide and curved, or phaseoliform, (5.8-)6.2-7.7(-8) $\times$ (2.1-) 2.2-2.9(-3.1) $\mu \mathrm{m}, \mathrm{L}=6.91 \mu \mathrm{m}, \mathrm{W}=2.55 \mu \mathrm{m}$, $\mathrm{Q}=2.61-2.71(\mathrm{n}=120 / 3)$.

Specimens examined: Finland. Uusimaa: Espoo, Tremanskärr, Pinus sylvestris, 31.VII.1994 Niemelä 5781, $5782(\mathrm{H})$. Kirkkonummi, Finnträsk, P. sylvestris, 24.VI.1993 Niemelä 5663 (H). Inarin Lappi: Inari, Haukijärvet, P. sylvestris, 18.X.1999 Kulju 281/99; Kaitavaara, P. sylvestris, 20.X.1999 Kulju $321 / 99$ (H, OULU). Sweden. Gotland: Hejnum, $P$. sylvestris, 27.XII.1935 Pettersson (UPS). Russia. Leningrad Region: Tikhvin Dist., Veps Forest, P. sylvestris, 24.V. 2000 Miettinen, 25.V.2000 Miettinen 2016, 6.VI.2000 Hölttä $(\mathrm{H})$.

\section{Fibroporia norrlandica (Berglund \& Ryvar- den) Niemelä, comb. nova. - Fig. 3}

Basionym: Oligoporus norrlandicus Berglund \& Ryvarden, Cryptogamie Mycol. 21:145, 2000. Holotype: Sweden. Norrbotten: Gällivare, Granlandet Nat. Res., Picea abies, VIII.1998 Berghund $47562(\mathrm{O})$.

Under Oligoporus norrlandicus this species was recently described from northern Sweden (Berglund \& Ryvarden 2000). Here it is also reported as new to Finland and France. The species has white, thin and resupinate basidiocarps on coniferous wood. The consistency of dry specimens is fragile and fruit bodies detach easily from the substrate; this is due to the monomitic subiculum, composed of a loose network of mostly thin-walled hyphae.

The description of the species was very brief, and some essential characteristics can be added. In the subiculum there are, beside the very thinwalled hyphae, also thick-walled ones. The latter have repeated septa with clamp connections, and so they could best be considered to be sklerified generative hyphae. They are present in some specimens (e.g. the type) and sections, but absent in others. Many of the subicular hyphae have ampullaceous, swollen sections close to the septa. 
Basidiospores are ellipsoid with truncate ends, and often they are somewhat deflated. What is important is that the wall is rather thick, not thin as reported before; it has a faint blue tint in Cotton Blue, and does not stain in IKI. A small, distinct guttule is characteristic. Spores measure (4.6-)4.9-6.2(-7.5) × (2.6-)2.7-3.5(-4.3) $\mu \mathrm{m}$, $\mathrm{L}=5.45 \mu \mathrm{m}, \mathrm{W}=3.11 \mu \mathrm{m}, \mathrm{Q}=1.66-1.81(\mathrm{n}=180 / 6)$.

Chlamydospores in the subiculum are ovoid or truncate, thick-walled, negative in IKI and staining only faintly or not at all in Cotton Blue, $(5.1-) 5.7-8.8(-12.5) \times(3.2-) 3.6-4.8(-5.4) \mu \mathrm{m}$, $\mathrm{L}=6.90 \mu \mathrm{m}, \mathrm{W}=4.14 \mu \mathrm{m}, \mathrm{Q}=1.55-1.89(\mathrm{n}=120 / 4)$.
The contents of the chlamydospores are homogeneous, or uniformly minutely granulate.

These characters fit rather well with the genus Oligoporus sensu stricto, comprising $O$. rennyi (Berk. \& Broome) Donk (type of the genus), $O$. sericeomollis (Romell) Bondartseva and O. ptychogaster (F. Ludw.) Falck. However, their thickwalled spores as well as the chlamydospores, when present, are strongly cyanophilous. By its spore characters $F$. norrlandica fits better with the genus Fibroporia, i.e., F. gossypium (Speg.) Parmasto and F. vaillantii (DC. : Fr.) Parmasto. Hyphal structure in the trama, and especially the
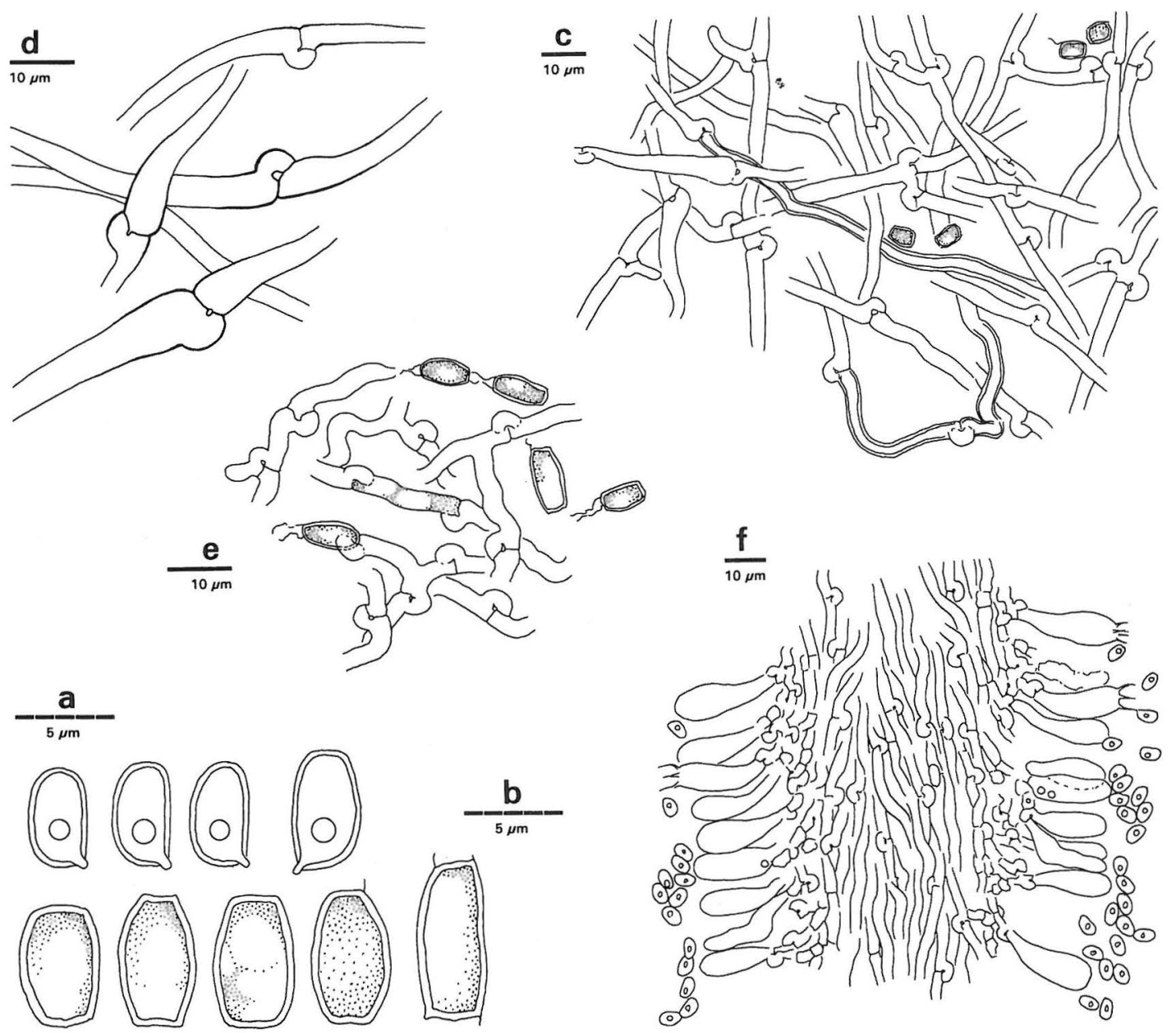

Fig. 3. Fibroporia norrlandica (Berglund \& Ryvarden) Niemelä, drawn from holotype (O), mounted in CB. - a) basidiospores, b) chlamydospores, c) subiculum, d) swollen hyphae from subiculum, e) conidiogenous hyphae from subiculum, f) tube trama and hymenium. 
spores of $F$. gossypium are so similar to those of $F$. norrlandica that they could be confused if the structure of the subiculum is not carefully studied. Fibroporia gossypium has monomitic trama, but dimitic subiculum.

Another typical member of the genus Fibroporia is F. radiculosa (Peck) Parmasto. In Europe it is sometimes known by the name Poria saxonica Dörfelt (Vampola 1992), and also North American Fibroporia angulopora M.J. Larsen \& Lombard is considered to be a synonym of $F$. radiculosa (Ryvarden \& Gilbertson 1993).

The truncate shape and thickness of the wall make the spores of Fibroporia (e.g. F. norrlandica) look like those of the genus Perenniporia. In the latter genus, however, spores are dextrinoid and very strongly cyanophilous, and hyphal structure is dimitic with skeletal or skeleto-binding hyphae; they are white-rot fungi.

The genus Fibroporia, as understood here, is characterized by:

- truncate and thick-walled spores which are weakly but distinctly cyanophilous, IKI-;

- acyanophilous hyphae, hyphal system being monomitic (F. norrlandica), partly monomitic - partly dimitic (F. gossypium) or dimitic (F. vaillantii);

- chlamydospores, if present, negative in Cotton Blue or almost so;

- brown-rot fungi.

Spore wall thickness and cyanophily separate Fibroporia from Antrodia; the type of rot is different in Perenniporia. Oligoporus s.str. is the closest relative, consisting of brown-rot fungi, too; so far, only consistently monomitic fungi have been accepted to that genus. See also the note of Postia mappa below.

Specimens examined: Sweden. Norrbotten: Gällivare, Granlandet Nat. Res., Picea abies, VIII.1998 Berglund 47562 (O, holotype). Finland. Satakunta: Yläne, Vaskijärvi Strict Nat. Res., P. abies, 22.X.1993 Savola 1010 (H). Etelä-Savo: Pertunmaa, P. abies, (4.V.1993 Lindgren $363(\mathrm{H})$. Kainuu: Kuhmo, Louhivaara, P. abies, 23.IX.1994 Järveläinen $144(\mathrm{H})$. Oulun Pohjanmaa: Oulu, Sanginjoki, Pinus sylvestris, 7.XI.2000 Kulju 371/ 00 \& Halonen (H). Kittilän Lappi: Kittilä, Aakenustunturi, Picea abies, 29.VIII.2000 Niemelä 6833, Kinnunen \& Turunen (H). France. Vendée: Jare-sur-Mer, Pinus pinaster, 29.I.1998 Pieri (H).

\section{Junghuhnia fimbriatella (Peck) Ryvarden}

Originally described from North America, Junghuhnia fimbriatella also occurs in East Asia:
Kamchatka (Parmasto 1963a, Bondartseva 1998), NE China (Dai 2000), and in several Central European countries (Ryvarden \& Gilbertson 1993), but is not reported from North Europe (Hansen \& Knudsen 1997). Now OMI collected it from the Veps Forest, on fallen, fairly strongly rotten aspen trees, $60-70 \mathrm{~cm}$ in diameter. New to European Russia.

This polypore is a look-alike of J. lacera/separabilima (next species), but differs mainly by its spore dimensions. They are (2.1-)2.3-2.8(-3.2) $\times$ (1.7-)1.9-2.2(-2.4) $\mu \mathrm{m}, \mathrm{L}=2.52 \mu \mathrm{m}, \mathrm{W}=2.06 \mu \mathrm{m}$, $\mathrm{Q}=1.22(\mathrm{n}=180 / 6)$. Critical is the thickness of the spores: in J. fimbriatella the diameter is about 2 $\mu \mathrm{m}$, in $J$. lacera/separabilima about $3 \mu \mathrm{m}$.

Specimens examined: Russia. Leningrad Region: Tikhvin Dist., Veps Forest, Populus tremula, 3.VI.2000 Miettinen 2091, 4.VI.2000 Miettinen 2107, 2109 (H). Czech Republic. Bohemia: Šumava, Boubinský prales, Fagus sylvatica, 4.IX.1970 Pouzar (H, ex PRM 870821). Slovakia. Slovenské Rudohorie: Čierny Balog, Dobročký prales, Ačer platanoides, 9.X.1993 Vampola (Polyporales Exs. Čechosl. 111, H). U.S.A. Washington: Olympic Peninsula, Populus nigra, 9.IX.1957 Lowe et al. $8326(\mathrm{H})$. Canada. Quebec: Boischâtel, Ulmus americana, 9.X.1971 Sirard $316(\mathrm{H}$, ex DAOM 153386). Ste. Foy, Quercus rubra, 24.X.1971 Sirard 310 (H, ex DAOM 153395). Ontario: Renfrew, Acer saccharum, 23.X.1984 Ginns 08646 \& Redhead (H, ex DAOM 191083).

\section{Junghuhnia lacera (P. Karst.) Niemelä \& Kin- nunen, comb. nova.}

Basionym: Physisporus lacer P. Karst., Meddel. Soc. Fauna Flora Fennica 9: 69, 1882. Lectotype (here designated): Finland. Etelä-Häme: Asikkala, Salix ('Pinus'), III.1863 Norrlin, herb. P. Karsten $3174(\mathrm{H})$.

Syn. Chaetoporus separabilimus Pouzar, Česká Mykol. 21:210, 1967. Holotypus: Slovakia, Jablunkov, Fagus sylvatica, 23.VIII.1966 Kotlaba \& Pouzar (PRM 625768).

The lectotypification of this species was thoroughly discussed by Teuvo Ahti and Seppo Huhtinen (in herb.), and their proposal is followed here. Karsten (1882) reported the specimen to be collected on pine, but in fact the substrate is Salix, as identified from underlying wood by Viljo Kujala (in herb.).

This species was previously known as Junghuhnia separabilima (Pouzar) Ryvarden, described from Slovakia (Pouzar 1967). Niemelä (1994) used the name $J$. lacera tentatively; the combination was not officially made because of 
doubts on the identity of the type, as it was reported from a coniferous host. In some recent publications (e.g. Hansen \& Knudsen 1997) the genus Junghuhnia Corda was merged in Steccherinum Gray; indeed the two are very similar microscopically. We refrain from using the latter generic name until its relationships with the sanctioned name Irpex Fr. are settled. This nomenclatural problem was discussed by Niemelä (1998a).

The spores of Junghuhnia lacera are subglobose, IKI-, CB-, (3.1-)3.8-4.9(-5.6) ×(2.7-)2.93.5 $(-3.8) \mu \mathrm{m}, \mathrm{L}=4.26 \mu \mathrm{m}, \mathrm{W}=3.16 \mu \mathrm{m}, \mathrm{Q}=1.26-1.51$ $(\mathrm{n}=280 / 6)$.

There are many records from Finland, ranging from the southern coast up to Lapland in the north. Lositskaya (1998) reported this species from the Karelian Republic, and Bondartseva (1998) and Zmitrovich (1999a) from the Leningrad Region.

Specimens examined: Finland. Varsinais-Suomi: Kemiö, angiosperm, 27.IX.1967 Niemelä. Etelä-Häme: see lectotype. Pohjois-Karjala: Lieksa, Patvinsuo Nat. Park, Populus tremula, 15.IX.1989 Penttilä 1257. Perä-Pohjola: Tervola, Pisavaara Strict Nat. Res., P. tremula, 4.IX.1991 Kotiranta 9814. Slovakia. Slovenské Rudohorie: Čierny Balog, Dobročký prales, Fagus sylvatica, 3.VIII.1973 Niemelä et al. (All in H)

\section{Junghuhnia pseudozilingiana Parmasto}

Junghuhnia pseudozilingiana was described from Estonia (Parmasto 1959), where it is known in several places. Since that time very few new finds have been done. In Russia Bondartseva (1964) and Noskov (2000) reported it from Tosno Dist., Leningrad Region, and the species is very rare in Finland (Niemelä 1981; map in Kotiranta \& Niemelä 1996). OMA and OMI collected it in the Veps Forest, listed below. The habitat was mesic, hardwood-dominated mixed forest with birch, aspen and spruce. The species typically grows on aspen, on and around dead basidiocarps of Phellinus tremulae (Bond.) Bond. \& Borisov.

Specimen examined: Russia. Leningrad Region: Tikhvin Dist., Veps Forest, Populus tremula, 5.VI.2000 Miettinen $2126(\mathrm{H})$.

\section{Perenniporia tenuis (Schwein.) Ryvarden}

This is a rare species throughout Europe. Perenniporia tenuis has been found seven times in Finland (Kotiranta \& Niemelä 1996, Martikainen et al. 2000), once on Alnus, and otherwise on Populus tremula. In neighbouring Russia Bondartseva (1964) reported it as "Fomitopsis unita (Pers.) Bond. f. pulchella (Schw.) Baxt.” from Tosno District, growing on birch. Now we report another find from the Veps Forest, on fairly strongly decayed, thin trunk of birch.

Specimen examined: Russia. Leningrad Region: Tikhvin Dist., Veps Forest, Betula, 24.V.2000 Manninen 664 (H).

Postia alni Niemelä \& Vampola, spec. nova. -Fig. 4.

Minutus, griseoalbus. Pileo 1-3 cm diam., lateraliter adnato, semiorbiculari, ad marginem acute attenuato, tomentoso, poris minutis. Sporis cylindricis, 4.4-6 × 1.1-1.3 $\mu \mathrm{m}$.

Holotypus: Slovakia. Malé Karpaty: Svätý Jur $15 \mathrm{~km}$ NE of Bratislava, alt. $130 \mathrm{~m}$, Alnus glutinosa, 12.X.1995 Vampola 32595 (H, isotype MJ).

Syn.: Polyporus alni Velen., České houby IVV: 650, 1922. Lectotype: Czech Republic. Moravia: Mouchnice, Alnus, VIII 1918 Sladký (PRC; isolectotype PRM 485099). Not Polyporus alni Sorokin, O nekotorykh boleznyakh vinograda: 142, pl. 22, 1892.

Annual, small, shelf-shaped or semiorbicular, white or cream, with very faint blue-gray shade on upper surface and deep in the tubes. Upper side matted or with very low tomentum, not hairy. Margin sharp, entire. Pores round, (4-)5-6(-7) per $\mathrm{mm}$, in old basidiocarps merged together and then larger; tube mouths very thin, entire. Section: context soft, when dry chalky, white; tubes concolorous or faintly blue-grey close to context; total thickness at base 3-10 mm.

Monomitic, hyphae with clamp connections, regular, IKI-, $\mathrm{CB}-$; in $\mathrm{KOH}$ outer dimensions remaining tunchanged, but hyphae becoming jelly-like and their walls swelling inwards so that only capillary lumen is seen. Context hyphae thin-walled, radially subparallel, with a few finger-like branches, (2.1-)2.8-4.5(-6.1) $\mu \mathrm{m}$ $(n=92 / 4)$. Tramal hyphae thin-walled close to dissepiment edge, thicker-walled in upper parts, interwoven with downward orientation, (2-)2.4 3.6 $(-4.3) \mu \mathrm{m}(\mathrm{n}=80 / 3)$. No cystidia, no cystidioles. Basidia clavate, $(10-) 12-13.5(-14) \times 3.8-4.2(-4.8)$ $\mu \mathrm{m}$, with 4 sterigmata, basidioles similar but shorter. Spores allantoid or very narrow cylindric, thinwalled, grey-coloured, weakly amyloid(?), CB-, 
$(4.1-) 4.4-6(-7) \times(1-) 1.1-1.3(-1.5) \mu \mathrm{m}, \mathrm{L}=5.06 \mu \mathrm{m}$, $\mathrm{W}=1.19 \mu \mathrm{m}, \mathrm{Q}=3.79-4.45(\mathrm{n}=240 / 8)$.

Jahn $(1973,1979)$ pointed out the heterogeneity of Postia caesia (Schrad. : Fr.) P. Karst. On deciduous hosts, for instance on Populus tremu$l a$, fruiting bodies are smaller than those on coniferous trees, paler in colour, not hairy but tomentose, and there is a difference in the spores, too. Jahn called that taxon 'Tyromyces subcaesius f. minor' (Jahn 1979 and in herb.), but he never validly published the name of the form. He addressed the taxon to Postia subcaesia (A. David) Jülich mainly because of similar spores. The real
P. subcaesia is a fairly large, fleshy species (David 1974), occurring in the Mediterranean.

Vampola (1994) studied the type materials of Velenovský, and among others found Polyporus alni Velen. (Velenovský 1920-1922, Pilát 1948) to be an older name for Jahn's 'f. minor'. The author TN studied the type, and agrees with Vampola's observation that an independent species is in question. Unfortunately $P$. alni Velen. is an illegitimate later homonym of Polyporus alni Sorokin, as stated by Donk (1974), and Velenovský's name cannot be used as the basionym. Sorokin's species is evidently Ganoderma lipsiense (Bat-

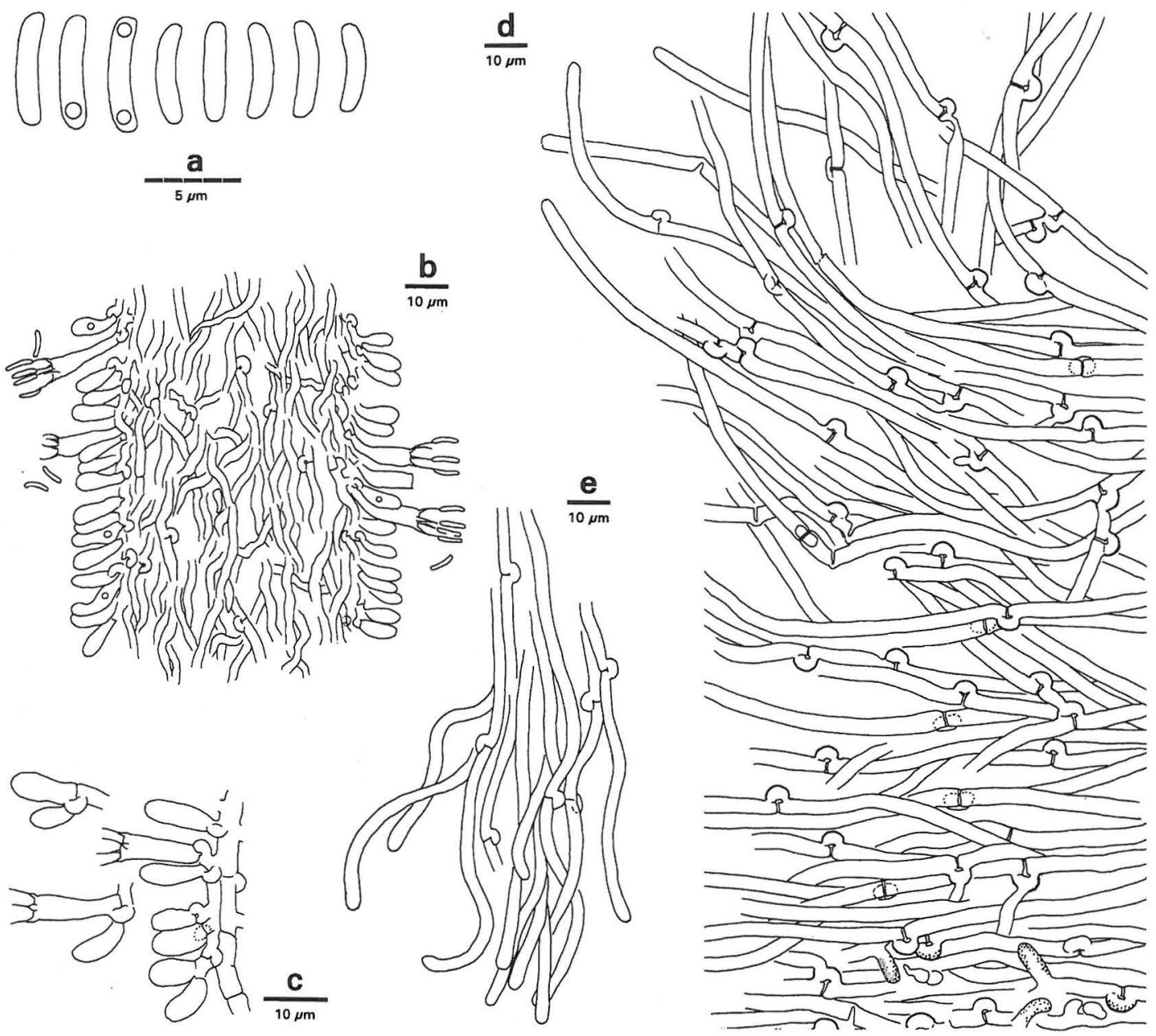

Fig. 4. Postia alni Niemelä \& Vampola, drawn from holotype (H), mounted in CB. - a) spores, b) tube trama and hymenium, c) hymenial cells, d) upper context and tomentum, e) hyphae from dissepiment edge. 
sch) G.F. Atk. (Bondartsev 1953). We anyhow want to retain the epithet given by Velenovský.

The species belongs to the Postia caesia complex, in which the spores are often reported to be amyloid. That is difficult to confirm: in fact spore walls are grey-coloured, evident in particular where seen en masse, for instance in $\mathrm{CB}$ or $\mathrm{KOH}$. Postia alni differs from $P$. caesia in having tomentose upper surface (instead of soft hairs), small pores, very narrow spores, and by growing on various angiosperm trees: Alnus, Corylus, Populus, Fagus, etc. Colour illustrations of the species are in Jahn (1979) and Niemelä \& Meike (1999).

The spores of Postia caesia are: (4.2-)4.4 $5.8(-6.7) \times 1.3-1.7(-1.9) \mu \mathrm{m}, \mathrm{L}=5.01 \mu \mathrm{m}, \mathrm{W}=1.49$ $\mu \mathrm{m}, \mathrm{Q}=3.12-3.62(\mathrm{n}=150 / 5)$. The spores of $P$. caesia are commonly $1.5 \mu \mathrm{m}$ in diam., while those over $1.3 \mu \mathrm{m}$ are very rare, exceptional in $P$. alni. Length/width ratio is usually $<3.5$ in $P$. caesia,$>4$ in P. alni.

Mr Max Pieri (Avignon, France) is thanked for his note on the dilemma between $P$. alni Sorokin and $P$. aln $i$ Velen. He is preparing a more detailed study on this group of fungi; its taxonomy seems to be more complicated than presented here.

Lositskaya (1997) reported the species as Oligoporus subcaesius (A. David) Gilb. \& Ryvarden from Valaam Island, Lake Ladoga in Karelian Republic. In Finland it is fairly common in herb-rich forests, but also in mesic spruce-dominated forests with aspen.

Specimens examined: Postia alni. Finland. VarsinaisSuomi: Bromarv, Corylus avellana, 15.IX.1974 Niemelä 505 \& Väisälä (H). Uusimaa: Vantaa, Mustavuori, Prunus padus, 5.X.1997 Niemelä 6155 \& Dai (H). Etelä-Häme: Lammi, Kotinen Virgin Forest, Populus tremula, 10.IX.1985 Niemelä 3272, 1.IX.1998 Niemelä 6342 (H). Germany. Westfalen: Detmold, Fagus sylvatica, 21.X.1976 Jahn ('Tyromyces subcaesius f. minor H. Jahn', H). Czech Republic. Bohemia: Kolín, Velký Osek, cf. Populus nigra, 13.IV.1994 Vampola 34494 (H, MJ). Moravia: see lectotype of Polyporus alni above. Slovakia. See holotype above.

Postia caesia: Finland. Åland: Lemland, Picea abies, 7.XII.1974 Fagerström. Etelä-Häme: Lammi, Kotinen Virgin Forest, P. abies, 16.IX.1986 Niemelä 3576. Längelmäki, Sinivuori Strict Nature Reserve, $P$. abies, 29.X.1977 Niemelä 1296. Poland. Łódzkie Prov.: Tomaszów Mazowiecki, Pusczca Pilicka, P. abies, 12.IX.1978 Mandke. Czech Republic. Moravia: Jihlava, Zbilidy, P. abies, 7.VIII.1993 Vampola, Polyporales Exs. Čechosl. 121. (All in H)

\section{Postia folliculocystidiata (Kotl. \& Vampola) Niemelä, comb. nova}

Basionym: Oligoporus folliculocystidiatus Kotl. \& Vampola, Czech Mycology 47: 59, 1993. Holotype: Czech Republic. Bohemia: Borovsko, Picea abies, 24.V.1964 Kotlaba \& Pouzar (PRM 604499).

The description (Kotlaba \& Vampola 1993) is detailed and well illustrated, and not much need to be added. The species is characterized by small, thin-walled basidiospores, IKI-, CB-, (3-) $3.2-4.4(-4.6) \times(1.9-) 2-2.4(-2.7) \mu \mathrm{m}, \mathrm{L}=3.80 \mu \mathrm{m}$, $\mathrm{W}=2.18 \mu \mathrm{m}, \mathrm{Q}=1.63-1.85(\mathrm{n}=90 / 3)$. Basidia have a striking shape: they are very narrow but long, cylindrical, 13-19 × 3.8-5 $\mu \mathrm{m}$. Pear-shaped, thinwalled cystidia are abundant, $13.5-24 \times 6-9 \mu \mathrm{m}$. The structure is monomitic with clamped septa, and the hyphae are IKI-, CB-, thick-walled in trama, and very thick-walled to subsolid in context. The very thick-walled hyphae of the context swell a little in $\mathrm{KOH}$, and all the hyphae become gelatinous and translucent, but do not dissolve in that medium. The hyphae are tightly interwoven in all parts except dissepiment edge, where they are parallel and slightly swollen at their tips, and on upper tomentum, where they make parallel bundles.

In the Finnish material the basidiospores are in general smaller $(\mathrm{L}=3.53-3.64 \mu \mathrm{m}, \mathrm{W}=2.09-2.17$ $\mu \mathrm{m})$ than in the type $(\mathrm{L}=4.22 \mu \mathrm{m}, \mathrm{W}=2.28 \mu \mathrm{m})$, but otherwise the shape and microscopy agree.

The thin-walled and acyanophilous spores rule out the genus Oligoporus in the strict sense, and it is here proposed that the species would fit better in the genus Postia. It seems to be related to $P$. floriformis (Quél.) Jülich and $P$. ceriflua (Berk. \& M.A. Curtis) Jülich; they are acystidiate polypores, and their hyphal walls are not that thick.

Kotlaba and Vampola (1993) report chlamydospores from the type. We found thick-walled asexual spores between the tomentum hyphae; they are strongly $\mathrm{CB}+$, IKI-, occurring all over but never in abundance, (4-)4.4-5.8(-6) $\times(2.9-)$ 3.1-3.7(-3.9) $\mu \mathrm{m}, \mathrm{L}=5.03 \mu \mathrm{m}, \mathrm{W}=3.43 \mu \mathrm{m}, \mathrm{Q}=1.47$ $(n=30 / 1)$.

Specimens examined: Czech Republic. See holotype above. Finland. Varsinais-Suomi: Nauvo, Berghamn, Pinus sylvestris, 31.X.1996 Heinonen \& Heinonen 24996, 14.X.1997 Heinonen \& Heinonen 105097 (TUR, H). 
Postia mappa (Overh. \& Lowe) M.J. Larsen \& Lombard

Dr Viljo Kujala (1891-1977) made his life-time work as the Professor of Forest Biology at the Finnish Forest Research Institute (Laine 1979). In addition to being a specialist of plant communities and floristics, he also devoted his skill to mycology. After retirement he continued to identify the incoming specimens of polypores in the herbaria HFR (Finnish Forest Research Institute) and H (Department of Botany, University of Helsinki). Many important early identifications were made by him. Reading fluently both English and Russian, Kujala could use the best manuals of that time, the magna opera of Overholts (1953) and Bondartsev (1953). The advanced generic concept of Bondartsev, based on microscopy, appealed to him more than the traditional morphological division that Overholts used.

While recently sorting out the collections of Matti Laurila, a specimen came out, identified by Kujala in 1966 as Fibuloporia mappa (Overh. \& Lowe) M.P. Christ. The identification was correct, as well as the note by Kujala, 'new to Finland'. The record was never published, however. At present the species is better known as Postia mappa (Hansen \& Knudsen 1997), or Oligoporus mappus (M.J. Larsen \& Lombard) Gilb. \& Ryvarden (Ryvarden \& Gilbertson 1994). That collection, dating back to the year 1936, remained the only one from the country, until RP refound the species in 1997 from a fallen aspen trunk.

Postia mappa is recognized by its thin, slightly resinous, resupinate basidiocarps which become chalky and crack upon drying, and in particular by its very long, rod-shaped spores, (7.4-) 8.5-10.8(-12.1) × (2-)2.5-3.1(-3.3) $\mu \mathrm{m}, \mathrm{L}=9.66$ $\mu \mathrm{m}, \mathrm{W}=2.84 \mu \mathrm{m}, \mathrm{Q}=3.11-3.62(\mathrm{n}=90 / 3)$. Niemelä (1985b) discussed the species in North America and illustrated its microscopy. In that paper $P$. mappa was considered to be dimitic and to belong to the genus Fibroporia. The interpretation was wrong, however: the thick-walled hyphae occasionally found in the subiculum close to the substrate, are merely sklerified generative hyphae; the spores are very thin-walled.

Postia mappa is very rare in North Europe. There is one find from Swedish Lapland (Olofsson 1996) and one from Denmark (Christiansen 1960). Bondartseva (1964) reported it from Northwest Russia (Leningrad Region, Kingisepp Dist.).
Specimens examined: Finland. Satakunta: Kankaanpää, Salix caprea, 26.VII.1936 Laurila 1102 (H). Pohjois-Savo: Savonranta, Populus tremula, 12.X.1997 Penttilä 11756 (H). U.S.A. New York: Newcomb, gymnosperm, 29.VIII.1942 Lowe 2312 (SYRF, paratype). Canada. Quebec: Poste-de-la-Baleine, Picea glauca, 6.VIII.1982 Niemelä 2669 (H).

Pycnoporellus alboluteus (Ellis \& Everh.) Kotl. \& Pouzar

While Pycnoporellus fulgens (Fr.) Donk is found fairly frequently in, e.g., Russian Karelia, its bigger-sized kin $P$. alboluteus is a true rarity throughout Europe. There are six finds from northern and eastern Finland (Oulun Pohjanmaa prov:: Pudasjärvi, Syöte and Sammalharju; Koillismaa prov.: Taivalkoski, Salmitunturi, 2 sites; Perä-Pohjola prov.: Tervola, Pisavaara Strict Nature Reserve and Rovaniemi, Kivalo). Parmasto (1963b) and Hermansson (1997) report the species in Komi Republic, but to our knowledge it has not been reported from NW Russia.

During the present inventory OMA found the species in the Veps Forest, from a fallen trunk of spruce, $20 \mathrm{~cm}$ in diameter. The fungus was growing on fairly rotten wood in lush, herb-rich slope forest. Another collection of OMA is from the Onega Peninsula; basidiocarps emerged from a 40 -cm-thick trunk of spruce in a seepage slope, in virgin spruce-dominated forest.

Pycnoporellus alboluteus is considered to be extinct in Norway (Strandberg \& Strandberg 1991), and there are two records from Sweden (Olofsson 1996). Elsewhere in Europe this showy species is known from the Białowieża forest in Poland (Domański 1972), Slovakia (Kotlaba 1984), and Ukraine and Croatia (Tortić 1974). There is one find from the Tomsk Region, Russian Siberia (Bondartsev 1953) and another from Tyumen (Bondartseva 1998), east of Ekaterinburg. In North America it is more frequent, albeit rare.

Specimens examined: Russia. Leningrad Region: Tikhvin Dist., Veps Forest, Picea abies, 6.VI.2000 Manninen 847. Archangel Region: Onega Peninsula, $P$. abies, 26.VI.1999 Manninen 72. (All in H)

\section{Rigidoporus crocatus (Pat.) Ryvarden}

The species is extremely rare in Finland, found three times only; the Finnish localities are listed by Renvall and Junninen (1999). In Russian Karelia, however, Rigidoporus crocatus is found re- 
peatedly (Bondartseva 1964, Noskov 2000, Siitonen et al. 2001, and below). Habitats are usually fern-rich mixed forests, dominated by spruce. Some of the forests were fairly open, for instance in successional stage after extensive windfalls. Most finds are from old, dense forests. The 6-7 observations by RP from Russian Karelia all are from birch or aspen. Surprisingly many basidiocarps were found from spruce. Broadleaved trees (birch, alder) are commoner hosts further west in North Europe. The trunks were fairly strongly decayed (decay stages 3 to 4; scale according to Renvall 1995), (25-)35-60 cm in diameter. The species is also known from Estonia (see list below), but not from the other Nordic countries (Hansen \& Knudsen 1997).

Specimens examined: Estonia. Pärnumaa: Saarde Dist., Viisireiu, Alnus glutinosa, 17.VII.1996 Niemelä 6011, 6012 \& Parmasto, Kõljalg \& Dai. Russia. Leningrad Region: Tikhvin Dist., Veps Forest, Picea abies, 26.V.2000 Manninen 690, 27.V.2000 Miettinen 2030 \& Syrjänen, 28.V.2000 Manninen 723, 6.VI.2000 Miettinen 2171, 2.VI.2000 Hottola 25; Betula, 31.V.2000 Manninen 764a. Sverdlovsk Region: Kirovgrad, Visim Nature Reserve, Betula, 17.IX.1994 Kotiranta 11808. (All in $\mathrm{H}$ )

Sistotrema dennisii Malençon - Fig. 5.

Sistotrema dennisii is separated from the other resupinate poroid Sistotrema species by its nar- row cylindric spores, in our material (4.1-)4.3-5 $(-5.2) \times(2-) 2.1-2.3(-2.4) \mu \mathrm{m}, \mathrm{L}=4.73 \mu \mathrm{m}, \mathrm{W}=2.21$ $\mu \mathrm{m}, \mathrm{Q}=2.14(\mathrm{n}=60 / 2)$. The species is very rare in North Europe (Eriksson et al. 1984). A collection was first identified by OMA from Finnish Lapland and confirmed by Heikki Kotiranta; later another collection was determined by ML from southern Finland. These are the first ones so far found from the country. In addition to the narrow spores, $S$. dennisii is characterized by the abundance of fatty guttules in the hyphae, and very short but thick basidia with 6,7 or 8 sterigmata. The poroid basidiocarps are cottony, white, and usually very small.

Specimens examined: Finland. Etelä-Häme: Janakkala, Picea abies, 8.IX.2000 Salonen 6. Inarin Lappi: Inari, Pinus sylvestris, 30.IX.2000 Pasanen. (All in H)

\section{Skeletocutis borealis Niemelä}

The description of Skeletocutis borealis was based on a few Swedish and Finnish collections only (Niemelä 1998b). Now further material was obtained from inventories in East Finland and Finnish Lapland. A characteristic habitat is herbrich mixed forest on a river- or brookside, where the microclimate is humid. The fungus mostly grows on thin trunks of Prunus padus or other deciduous trees, pressed down by heavy snow, and hanging $10-20 \mathrm{~cm}$ over the ground level.
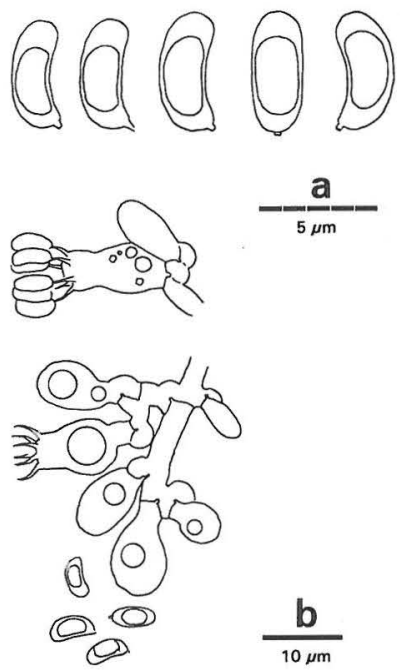

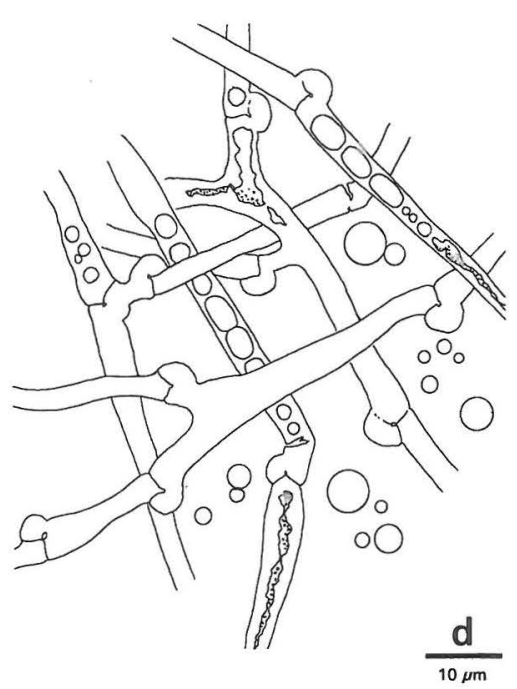

Fig. 5. Sistotrema dennisii Malençon, specimen 30.IX.2000 Pasanen (H). - a) basidiospores, b) basidium, basidioles and subicular hyphae, c) hyphae from dissepiment edge, d) subiculum. 
Skeletocutis borealis is perennial, and the margins of the basidiocarp are thick, finally making up a compact, minute pileus, projecting a few millimetres only. Fructifications tend to be extensive, covering up to $50 \mathrm{~cm}$ or even a metre of the lower side of fallen trunk, which is still corticated and fairly hard. Fresh colour is cream, and a faint salmon tint develops upon drying. In the field the species reminds vigorously growing, young Datronia stereoides (Fr.) Ryvarden. A colour photograph by Matti Kulju was published in Niemelä and Meike (1999).

Specimens examined: Finland. Kainuu: Kuhmo, Vattuvaara, Betula, 1.X.1999 Eskelinen (KUO, H). Kittilän Lappi: Kittilä, Kukasjärvi, Prunus padus, 23.VIII.1999 Niemelä 6522 \& Dai $3166(\mathrm{H})$. Kolari, Äkäslompolo, Varkaankuru, P. padus, 28.VIII.2000 Niemelä 6811, $6813 \&$ Kinnunen, Turunen $(\mathrm{H})$.

\section{Skeletocutis friata Niemelä \& Saarenoksa, nom. novum}

Syn. Skeletocutis friabilis Niemelä \& Saarenoksa, Acta Bot. Fennica 161: 16, 1998 [non S. friabilis (Corner) Quanten ('friabile'), Opera Bot. Belgica 11: 228, 1997]. Holotype: Finland. Uusimaa: Sipoo, Östersundom, Alnus glutinosa, 25.VIII.1990 Saarenoksa $27490(\mathrm{H})$.

Skeletocutis friabilis Niemelä \& Saarenoksa was recently described from southern Finland (Niemelä 1998b), growing on twigs of alder in a coastal herb-rich forest. However, there is another, tropical Asian species with the same name: Skeletocutis friabilis (Corner) Quanten ('friabile'), occurring in Papua New Guinea (Quanten 1997). That combination was published a couple of months earlier (1 December 1997) than our species (23 February 1998). Therefore the change of name is needed.

The species seems to be very rare. In recent years we have tried to refind it at its type locality or elsewhere in southern Finland, but in vain. The small size may make it hiding, but in the microscope the identification should be fairly easy because of rather thick spores and almost monomitic hyphal structure, with only few skeletal hyphae in the subiculum and upper parts of tube trama. A more complete description was published by Niemelä (1998b).

\section{Skeletocutis krawtzewii (Pilát) Kotl. \& Pouzar}

In a review on Skeletocutis, Niemelä (1998b) briefly discussed many poorly known or dubious species addressed to the genus. Among them there was $S$. krawtzewii, so far known from the type from Siberia only (Kotlaba \& Pouzar 1991). Now OMA collected good and ample material from NW Russia, east of Lake Ladoga (the Veps Forest, see Popova \& Noskov 1999), hence the second find of the species. The type specimen is very small, and this new find makes it easier to understand the characteristics of this rarity. The basidiocarps are resupinate, annual or perhaps short-lived perennial but thin ( $\max .1 \mathrm{~mm}$ ), creamcoloured overall but attaining ochraceous colour where bruised. Pores are round, 6-7(-8) per mm. Spores are very thin-walled, in the new specimen $\mathrm{L}=3.40 \mu \mathrm{m}, \mathrm{W}=1.85 \mu \mathrm{m}$, and the spore dimensions when this and the type are combined are: (3.4-)3.5-4.2(-4.6) × (1.6-)1.7-2(-2.2) $\mu \mathrm{m}, \mathrm{L}=3.61$ $\mu \mathrm{m}, \mathrm{W}=1.86 \mu \mathrm{m}, \mathrm{Q}=1.84-2.04(\mathrm{n}=60 / 2)$. Often the spores bear 1-4 small guttules.

Externally the species looks like a young stage of Skeletocutis stellae (Pilát) Jean Keller, but that species is more hard when dry, has smaller pores, and is truly perennial and finally thick. The cream colour brings in mind Junghuhnia luteoalba (P. Karst.) Ryvarden. In the microscope the short, thick and extremely thin-walled spores of $S$. krawtzewii are characteristic; the spores are even more broad than in $S$. borealis, which, in addition, is very oily in the microscope, and the hyphae of the dissepiment edges are wide and often inflated. Microscopic mounts of S. krawtzewii show no oily exudates in $\mathrm{CB}$, and the richly encrusted hyphae of the dissepiment edges are narrow.

The type was collected from Larix (Kotlaba \& Pouzar 1991, Niemelä 1998b) and the new collection derives from bark of spruce, a thin trunk fallen in spruce forest (Equisetum sylvaticum variant: Påhlsson 1995: 149). The species may be eastern in Eurasia, favouring a continental climate.

Specimens examined: Russia. Leningrad Region: Tikhvin Dist., Veps Forest, Picea abies, 2.VI.2000 Manninen $816(\mathrm{H})$. Siberia: Khakassia, Larix sibirica, XII.1931 Pilát (PRM 779989, holotype).

\section{Skeletocutis ochroalba Niemelä}

This polypore was described from Quebec, northern Canada, the timberline forests close to Kujjuarapik village along the Great Whale River (Niemelä 1985b). For a long time the original col- 
lections remained the sole records of the species, until it was recollected in Estonia and Sweden in the 1990s (see Olofsson 1996 and the list of specimens below). Later TN and Yu-Cheng Dai found it in the Changbai Shan virgin forest in northeastern China (Dai 2000), growing on fallen Picea trunk. Spruce was the host tree genus of the previous records, too.

In 2000 a beautiful basidiocarp of $S$. ochroalba was collected by Ms Maija Ihantola, during a field-course of polypores, in Central Finland. Also there it grew on spruce, a fairly thin, fallen trunk in dense lakeside spruce forest. The species was found by the border of the Kotinen Nature Reserve (see Holec \& Niemelä 2000), although the exact collecting site falls just outside the virgin forest.

In the microscope Skeletocutis ochroalba is similar to $S$. nivea (Jungh.) Jean Keller: both have very narrow spores $(<1 \mu \mathrm{m})$, and the context and subiculum are dimitic or trimitic, while tube trama is monomitic. Macroscopy and ecology differ, however. Skeletocutis nivea tends to produce effused basidiocarps, whenever possible, and its pilei develop only in a later stage of fruit-body development. Often the resupinate basidiocarps are several centimeters (even $10-20 \mathrm{~cm}$ ) wide along the substrate, which is an angiosperm tree. The overall colour of $S$. nivea is white, upper side becoming finally black-brown, and pore side attaining greenish or grey tints. Skeletocutis ochroalba is warm ochraceous or reddish orange on its upper side, and pale salmon can be seen on fresh lower side. When drying the pores may attain a greenish grey hue, however. Basidiocarps are always compact, knot- or buttonshaped, and not effused. Usually only one or two fruit bodies are seen on a fallen spruce trunk. The blunt edge turns downwards, and so the pore surface is somehow concave. The rather bright ochraceous colour of the pileus is similar to that of very young Fomitopsis pinicola (Sw. : Fr.) P. Karst., and it may be mistaken for a fingertip-size, early stage of that fungus. A closer study at once reveals the differences, for instance the very small pores, (5-)6-8 per mm, and soft-corky consistency of $S$. ochroalba.

Specimens examined: Estonia. Harjumaa: Tallinn, Picea abies, 13.IX.1992 Jakobson 158247 (TAA 2026). Sweden. Dalarna: Rättvik, P. abies, 9.IX.1996 Sörenmark (herb. Malte Edman 770). Finland. Etelä-Häme: Lammi, Kotinen Virgin Forest, P. abies, 12.IX.2000
Ihantola \& Niemelä 6881 (H). Canada. Quebec: Postede-la-Baleine, Picea glauca, 30.VII.1982 Niemelä 2585 (H), 7.VIII.1982 Niemelä 2689 (H, DAOM), 2695 (holotype, H), 2697 (H). China. Jilin Prov.: Antu, Changbai Virgin Forest, alt. 1200 m, Picea jezoensis, 18.IX.1998 Niemelä 6408 \& Dai 2993 (H).

\section{A catalogue of polypores collected in NW Russia}

The following list (Table 1) summarizes the studies of the present authors: polypores collected in Russian Karelia and adjacent areas in Leningrad and Archangel Regions. Terrestrial polypores (Albatrellus, Boletopsis, Coltricia) are omitted. The genus Phellinus is treated in a wide sense, as is Phellinus igniarius, including for instance P. alni (Bond.) Parmasto, P. cinereus (Niemelä) M. Fischer and $P$. nigricans (Fr.) P. Karst., but excluding P. laevigatus (P. Karst.) Bourdot \& Galzin, $P$. lundellii Niemelä and $P$. populicola Niemelä. Another species in Phellinus sensu lato, Porodaedalea niemelaei M. Fischer, was recently described from Finland, growing on larch (Fischer 2000); it is related to Phellinus pini (Brot. : Fr.) A. Ames and P. chrysoloma (Fr.) Donk. The presence of this newly described species was not checked during the survey, but in one picture, taken by RP in Vodlozero Park, there is a polypore looking like $P$. pini, growing on big standing Larix sibirica; it is most probably this new species. In Vodlozero there is one of the westernmost native occurrences of Larix sibirica. The name Porpomyces mucidus (Pers. : Fr.) Jülich is used for the species more commonly known as Fibuloporia mucida (Pers. : Fr.) Niemelä, or Ceriporiopsis mucida (Pers. : Fr.) Gilb. \& Ryvarden.

Species are listed according to the East Fennoscandian biogeographical provinces (Fig. 2), when applicable. Furthermore, some important forest reserves and areas of old-growth forest are listed separately. They are numbered in Table 1 as follows, and mapped on Fig. 2:

(1) Veps Forest,

(2) Kivach Nature Reserve,

(3) Vodlozero National Park,

(4) forests SE of the Kostomuksha Strict Nature Reserve,

(5) the planned Kalevala National Park,

(6) Onega Peninsula. 
Table 1. Records of polypores from Russian Karelia and some neighbouring areas by the present authors. Biogeographical province names are abbreviated and shown on Fig. 2; numbers refer to special, intensively studied localities (see Fig. 2). Species recorded here for the first time from NW Russia are indicated with an asterisk (*).

\section{Province or special area: Vep Ka lk $\mathrm{KI}$ Kol Kb Kon Kiva Kton Vodl Kpoc Kost Kalev Kpor Kk Oneg} Special area\#: 1

\section{SPECIES}

Amylocystis lapponica (Romell) Singer

Anomoporia bombycina (Fr.) Pouzar

Anomoporia kamtschatica (Parmasto) Bondartseva

Antrodia albobrunnea (Romell) Ryvarden

Antrodia crassa (P. Karst.) Ryvarden

Antrodia heteromorpha $(\mathrm{F} \cdot \mathrm{F}$. $)$ Donk

Antrodia infirma Renvall \& Niemelä

Antrodia macra (Sommerf.) Niemela

Antrodia mellita Niemelä \& Pentiliä

Antrodia primaeva Renvall \& Niemelä

Antrodia pulvinascens (Pilát) Niemelä

Antrodia serialis (Fr.) Donk

Antrodia sinuosa (Fr.) P. Karst.

Antrodia sitchensis (D.V. Baxter) Gilb. \& Ryvarden

*Antrodia sordida Ryvarden \& Gilb.

Antrodia xantha (Fr. : Fr.) Ryvarden

*Antrodiella americana Ryvarden \& Gillb.

Antrodiella citrinella Niemelä \& Ryvarden

*Antrodiella faginea Vampola \& Pouzar

*Antrodiella pallasii Renvall, Johannesson \& Stenlid

Antrodiella semisupina (Berk \& M.A. Curtis) Ryvarden

Aurantioporus fissilis (Berk. \& M.A. Curtis) H. Jahn

Bierkandera adusta (Willd . Fr.) P. Karst.

Byssocorticium mo liculum (Bourdot) Jülich

Ceriporia reticulata (H. Hoffm. : Fr.) Domański

Ceriporiopsis aneirina (Sommerf.) Domański

Ceriporiopsis resinascens (Romell) Domański

Cerrena unicolor (Bull. : Fr.) Murrill

Climacocystis borealis (Fr.) Kotl. \& Pouzar

Daedaleopsis confragosa (Bolton : Fr.) J. Schröt.

Datronia mollis (Sommerf.) Donk

Dichomitus squalens (P. Karst.) D.A. Reid

Diplomitoporus crustulinus (Bres.) Domański

$\begin{array}{llll} & & & \\ & + & & + \\ & + & & \\ & + & & \\ & + & & \\ & & & \\ & + & & \\ & + & & \\ & + & & \\ & + & + & + \\ & + & + & + \\ & + & & + \\ & + & + & + \\ & + & & \\ & + & & + \\ & + & & \\ & & & \\ & & & \\ & & & \\ & + & + & \\ & & & \\ & + & & \\ & + & + & \\ & + & + & \\ & + & & + \\ & + & & \\ & + & + & \\ & + & & + \\ & & & \end{array}$


45

6

Daedaleopsis septentrionalis (P. Karst.) Niemelä

Diplomitoporus flavescens (Bres.) Domański

Diplomitoporus lindbladii (Berk.) Gilb. \& Ryvarden

Fomes fomentarius (L.: Fr.) Fr.

Fomitopsis pinicola (Sw. : Fr.) P. Karst

Fomitopsis rosea (Alb. \& Schwein. : Fr.) P. Karst.

Funalia trogii (Berk.) Bond. \& Singer

Ganoderma lipsiense (Batsch) G.F. Atk

Gelatoporia pannocincta (Romell) Niemelä

Gelatoporia subvermispora (Pilát) Niemelà

Gloeophyllum abietinum (Bull. : Fr.) P. Karst.

Gloeophyllum odoratum (Wulfen : Fr.) Imazeki

Gloeophyllum protractum (Fr.) Imazeki

Gloeophyllum sepiarium (Wulfen : Fr.) P. Karst.

Gloeoporus dichrous (Fr. : Fr.) Bres.

Gloeoporus taxicola (Pers. : Fr.) Gilb. \& Ryvarden

Hapalopilus rutilans (Pers. : Fr.) P. Karst.

Hapalopilus salmonicolor (Berk. \& M.A. Curtis) Pouzar

Haploporus odorus (Sommerf.) Bond. \& Singer

Heterobasidion parviporum Niemelä \& Korhonen

Hyphodontia paradoxa (Schrad. : Fr.) E. Langer \& Vesterholt

*Hyphodontia radula (Pers. : Fr.) E. Langer \& Vesterholt

Inocutis rheades (Pers.) Fiasson \& Niemelä

Inonotus obliquus (Pers. : Fr.) Pilát

Inonotus radiatus (Sowerby: Fr.) P. Karst.

Ischnoderma benzoinum (Wahlenb. : Fr.) P. Karst.

Junghuhnia collabens (Fr.) Ryvarden

*Junghuhnia fimbriatella (Peck) Ryvarden

Junghuhnia luteoalba (P. Karst.) Ryvarden

Junghuhnia nitida (Pers. : Fr.) Ryvarden

Junghuhnia pseudozilingiana (Parmasto) Ryvarden

Lenzites betulinus (L. : Fr.) Fr.

Leptoporus mollis (Pers. : Fr.) Quél.

*Oligoporus ptychogaster (F. Ludw.) Falck

Oligoporus rennyi (Berk. \& Broome) Donk

Oligoporus sericeomollis (Romell) Bondartseva

Onnia leporina (Fr.) H. Jahn

+
+
+
+
+
+
+
+
+
+
+
+
+
+
+
+
+
+
+
+
+
+
+
+
+
+
+
+
+
+
+
+
+
+
+
+
+
+

+
+
+
+
+
+
+
+
+
+
+
+
+
+
+
+
+
+
+
+
+
+
+
+
+
+
+
+
+
+
+
+

+
+
+
+
+
+
+
+
+
+
+
+
+
+
+
+
+
+
+
+
+

$+$

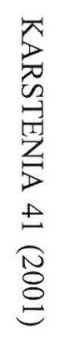


Parmastomyces mollissimus (Maire) Pouzar Perenniporia subacida (Peck) Donk

Perenniporia tenuis (Schwein.) Ryvarden

Phaeolus schweinitzii (Fr.) Pat.

Phellinus chrysoloma (Fr.) Donk

Phellinus conchatus (Pers. : Fr.) Quél.

Phellinus ferrugineofuscus (P. Karst.) Bourdot

Phellinus igniarius (L. : Fr.) Quél

Phellinus laevigatus (P. Karst.) Bourdot \& Galzin

Phellinus lundellii Niemelä

*'Phellinus' niemelaei (M. Fischer) comb. ined.

Phellinus nigrolimitatus (Romell) Bourdot \& Galzin

Phellinus pini (Brot. : Fr.) A. Ames

Phellinus populicola Niemelä

Phellinus punctatus (P. Karst.) Pilát

Phellinus tremulae (Bond.) Bond. \& Borisov

Phellinus viticola (Schwein. : Fr.) Donk

Physisporinus vitreus (Pers. : Fr.) P. Karst.

*Piloporia sajanensis (Parmasto) Niemelä

Piptoporus betulinus (Bull. : Fr.) P. Karst.

Polyporus brumalis (Pers. : Fr.) Fr.

Polyporus ciliatus $\mathrm{Fr}$. : Fr.

Polyporus leptocephalus (Jacq. : Fr.) Fr.

Polyporus pseudobetulinus (Pilát) Thorn, Kotir. \& Niemelä

Polyporus squamosus (Huds. : $\mathrm{Fr}$.) $\mathrm{Fr}$.

*Polyporus tubaeformis (P. Karst.) Ryvarden \& Gilb.

Porpomyces mucidus (Pers. : Fr.) Jülich

Postia alni Niemelä \& Vampola

Postia caesia (Schrad. : Fr.) P. Karst.

Postia guttulata (Peck) Jülich

Postia hibernica (Berk. \& Broome) Jülich

Postia lactea (Fr.) P. Karst.

Postia lateritia Renvall

Postia leucomallella (Murrill) Jülich

Postia lowei (Pilát) Jülich

Postia placenta (Fr.) M.J. Larsen \& Lombard

*Postia septentrionalis (Vampola) Renvall

Postia stiptica (Pers. : Fr.) Jülich 
Province or special area: Vep

k KI $\quad$ Kol

Kb Kon

Kiva Kton Vodl Kpoc Kost Kalev Kpor Kk Oneg

Special area\#: 1 3

4

Postia tephroleuca (Fr.) Jülich

Postia undosa (Peck) Jülich

Protomerulius caryae (Schwein.) Ryvarden

*Pycnoporellus alboluteus (Ellis \& Everh.) Kotl. \& Pouzar

Pycnoporellus fulgens (Fr.) Donk

Pycnoporus cinnabarinus (Jacq. : Fr.) P. Karst.

Rigidoporus corticola (Fr.) Pouzar

Rigidoporus crocatus (Pat.) Ryvarden

Rigidoporus populinus (Schumach. : Fr.) Pouzar

Sistotrema muscicola (Pers.) S. Lundell

Skeletocutis amorpha (Fr) Kotl \& Pouzar

${ }^{*}$ Skeletocutis biguttulata (Romell) Niemelä

Skeletocutis brevispora Niemelä

Skeletocutis carneogrisea A. David

Skeletocutis chrysella Niemelä

${ }^{*}$ Skeletocutis jelicii Tortić \& A. David

*Skeletocutis krawtzewii (Pilát) Kotl. \& Pouzar

Skeletocutis kuehneri A. David

Skeletocutis lenis (P. Karst.) Niemelä

Skeletocutis odora (Sacc) Ginns

Skeletocutis papyracea A. David

Skeletocutis stellae (Pilát) Jean Keller

Trametes hirsuta (Wulfen : Fr.) Pilát

Trametes ochracea (Pers.) Gilb. \& Ryvarden

Trametes pubescens (Schumach. : Fr.) Pilát

Trametes suaveolens ( $\mathrm{Fr}$.) $\mathrm{Fr}$.

*Trametes velutina (Fr.) G. Cunn.

Trametes versicolor (L. : Fr.) Pilát

*Trechispora hymenocystis (Berk. \& Broome) K.H. Larsson

Trechispora mollusca (Pers. : Fr.) Liberta

Trichaptum abietinum (Pers. : Fr.) Ryvarden

Trichantum fuscoviolaceum (Ehrenb. : Fr.) Ryvarden

Trichaptum laricinum (P. Karst.) Ryvarden

Trichaptum pargamenum (Fr.) G. Cunn.

*Tyromyces canadensis Overh. ex J. Lowe

\begin{tabular}{|c|c|c|c|c|c|c|c|c|c|c|c|c|c|c|}
\hline+ & + & & & & & + & + & & & + & & & & \\
\hline+ & + & & & & & & & & & + & & & & \\
\hline+ & + & & & & & + & + & + & + & + & & + & & + \\
\hline+ & & & & & & & & & & & & & & + \\
\hline+ & + & + & + & + & & + & + & + & + & & & & & \\
\hline+ & & & & & & & & & & & & & & \\
\hline+ & + & + & & & & + & + & + & + & + & + & + & + & + \\
\hline+ & & & & & & + & + & + & + & + & & & & \\
\hline \multirow[t]{2}{*}{+} & & & & & + & + & + & + & + & & & & & \\
\hline & & & & & & & & & & + & & + & & \\
\hline+ & & & & & & + & + & + & + & + & + & + & & \\
\hline \multirow[t]{2}{*}{+} & + & & & & & + & + & & & + & & + & & \\
\hline & + & & & & & + & + & + & + & + & + & + & & \\
\hline+ & + & & & & & & & & & + & & + & & \\
\hline \multirow[t]{2}{*}{+} & & & & & & + & + & + & + & + & & + & & + \\
\hline & & & & & & & & & & + & & + & + & \\
\hline \multicolumn{15}{|l|}{+} \\
\hline & + & & & & & + & + & + & + & + & & + & & \\
\hline & & & & & & & & + & + & + & + & + & + & + \\
\hline+ & & & & & & + & + & + & + & + & & + & + & \\
\hline & + & & & & & & & + & + & + & + & + & & \\
\hline+ & & & & + & & + & + & + & + & + & + & + & + & + \\
\hline+ & + & & & & & + & + & & & & & & & + \\
\hline+ & + & + & & & & + & + & + & + & + & + & + & + & + \\
\hline+ & & & & & & + & + & + & + & & & & & \\
\hline+ & & & & & & & & & & & & & & + \\
\hline+ & & & & & & + & + & & & & & & + & \\
\hline \multicolumn{15}{|l|}{+} \\
\hline+ & + & & & & & & & & & & & & & \\
\hline+ & + & & & & & + & + & + & + & + & & + & & + \\
\hline \multirow[t]{3}{*}{+} & + & + & & & + & + & + & + & + & + & + & + & + & + \\
\hline & + & & & & + & & & & & + & + & + & + & + \\
\hline & & & & & + & & & & & + & + & + & + & + \\
\hline \multirow[t]{2}{*}{+} & & & & & & + & + & + & + & + & + & + & + & + \\
\hline & & & & & & & & & & + & & + & & \\
\hline
\end{tabular}




\section{Discussion}

Old forests of North Europe still offer many new records: fungi new to the area, as well as undescribed species. In terms of species richness Russian Karelia and its surroundings clearly surpasses the forests found further west in the Nordic countries: Finland, Sweden and Norway. Even with our short periods of fieldwork, the remarkable number of 143 polypore species were found, altogether 12 of them being new to NW Russia (Tab. 1). Many of the previously unrecorded species are rare, such as Antrodia sordida, Pycnoporellus alboluteus and Skeletocutis krawtzewii.

Extensive areas in Russian Karelia are poorly investigated or virtually unstudied. This is the case, in particular, as to the province Kpor (see Tab. 1), the Karelian Isthmus (provinces $\mathrm{Ka}$ and Ik) and northern sides of Lake Ladoga (province $\mathrm{Kl}$ ). The provinces $\mathrm{Ks}$ and $\mathrm{Kk}$ and north- wards up to the northern timberline are practically unvisited.

A general impression is that many species classified as threatened in Finland are much more frequently found on the Russian side (Lindgren 2001, Siitonen et al. 2001). A good example is Rigidoporus crocatus. Higher species richness in Russian forests is a result of many favourable facts.

In Russian Karelia and adjacent areas in the east and south there are still considerable areas of truly virgin old-growth forests (Lloyd 1999, Lindén et al. 2000). This means, e.g., long continuity in the forest history, and high amounts of coarse woody debris: natural stumps, fallen trunks, and standing, long-ago dead, very old pine trees (the kelo trees in Finnish). Even in areas where light selective cuttings were performed, the forests have been allowed to regenerate naturally. What is most important is that in Russian Karelia modern forestry practices (thinning,

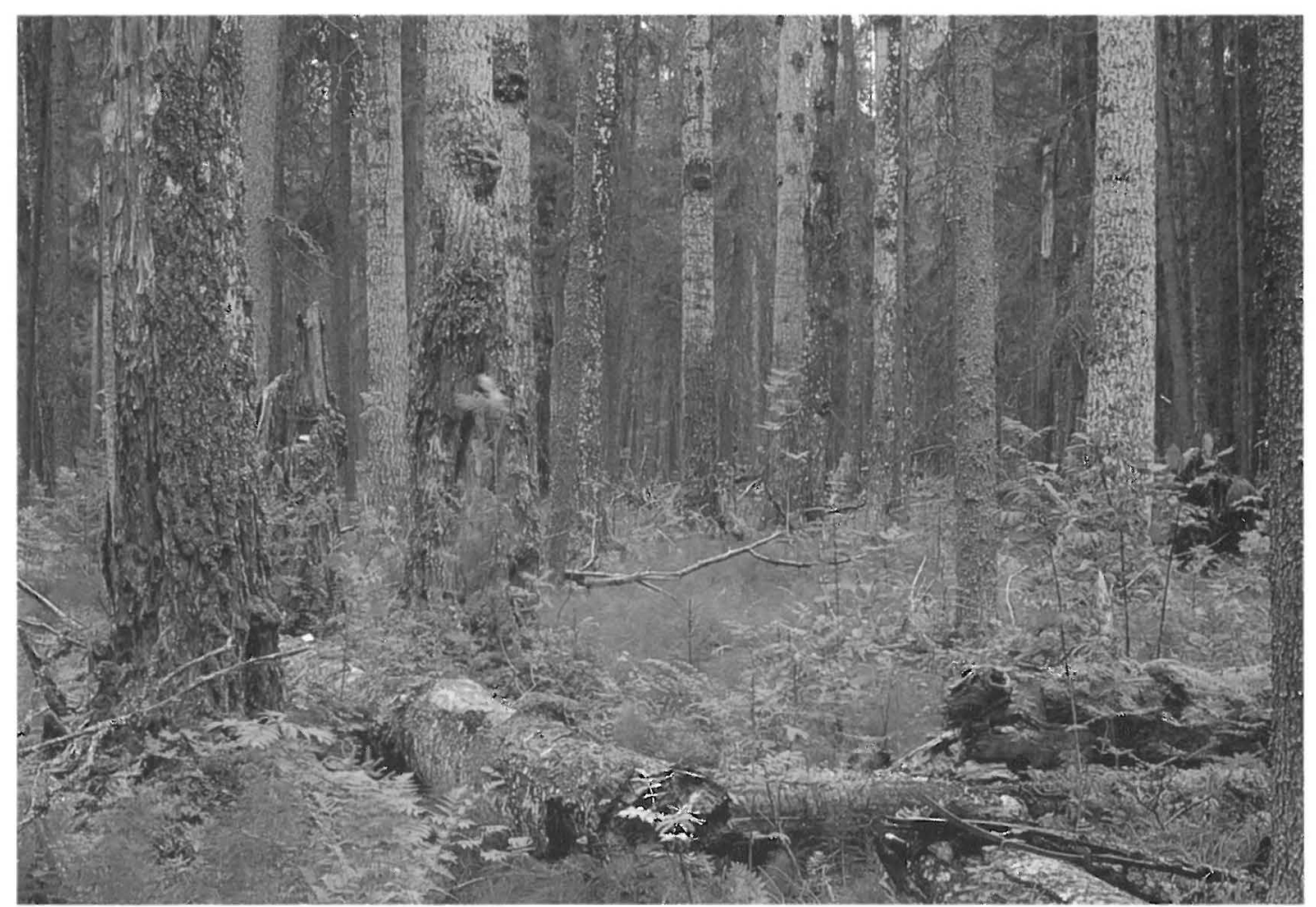

Fig. 6. Herb-rich mixed forest in Kivach Reserve, Russian Karelia. Common trees are Picea abies, Betula sp., and Populus tremula; seedlings of Sorbus aucuparia on the foreground. Photograph Reijo Penttilä 1997. 
clear-cutting, ditching and planting) have not been carried out in a large-scale systematic way.

For instance, in the Vodlozero Park and Kalevala District the areas of virgin forests are uninterrupted and extensive. In the Vodlozero Park most of the forests are old-growth, the proportion of stands over 140 years of age being $88 \%$ of the total forest area (Kukushin 1995). Hence fragmentation has not created distribution barriers or isolated populations, which is the case in most old-forest areas in Finland.

Kivach Reserve (Fig. 6), as well as Veps Forest, are largely situated on fertile soil, and herbrich forests are common in those areas. This favours fungi growing on broadleaved trees, as is seen from our list. Also Vodlozero Park is characterized by a high number of polypores specialized in angiosperm hosts. On the other hand, Kostomuksha and in particular Kalevala have more dry terrain, and fungi of spruce and pine are remarkable there. Again, the corresponding forests in the Finnish side are significantly poorer in species (Lindgren 2001).

A wide-scale conservation of extensive, unfragmented, old forests of Russian Karelia is of paramount importance. The greenbelt, or borderland running along the eastern side of Finland, is a valuable corridor for countless threatened species, both fungi, insects and other organisms. Together with other areas further east, it is an important source area for the fragmented Finnish nature, too: a haven from where rare species can reclaim their dispersal towards the west (Siitonen \& Martikainen 1994, Lindén et al. 2000).

There are dangers of future, however. The conservation status is unsettled in some main areas, e.g. Kostomuksha and Onega. Many invaluable areas are still uninventoried, and we don't know their status, where they are, and what will be lost if they are exploited. Finnish forestry industry is a special threat in particular for the forests close to the border: when conservation pressure and demand of wood is growing in Finland, large companies attempt to harvest cheap timber from neighbouring areas. Another kind of threat is waiting in Finland, too: the intensive, extensive and standardized way of forest management. If Finnish forestry practices are adopted to Russian Karelia, the unique diversity of Karelian oldgrowth forests may soon be lost.

Our list of species, together with previous studies (in particular, Bondartseva et al. 2000), offers a remarkable evidence of the high conservation value of the old forests of NW Russia. As regards the species diversity of old-growth forests, this northern wilderness belongs to the most valuable areas in the whole of Europe, and its high-level conservation is of primary importance.

Acknowledgements: Special thanks are due to the Ministry of Environment (Finland), which funded inventories in Onega Peninsula and Veps Forest, and some of the inventories by the Finnish Nature League in Karelia; without that support a great deal of records would have remained unrevealed. Pertti Salo selected questionably identified specimens for us to re-identify. Matti Kulju sent specimens of Fibroporia norrlandica and Diplomitoporus flavescens. Leif Ryvarden proposed many improvements to the manuscript. Teuvo Ahti solved some nomenclatural problems, traced Russian locality names, and revised the text throughout. Heikki Kotiranta joined in one field-trip to Vodlozero, gave comments and spore measurements of Sistrotrema dennisii, and forwarded a specimen of $F$. norrlandica; the latter was also sent to us by Max Pieri. Cooperation with Petr Vampola (Jihlava, Czech Rep.) and Max Pieri (Avignon, France) on the problems with Postia alni is gratefully acknowledged. Several colleagues and friends accompanied us in the field or otherwise helped. We forward our best thanks to Malte Edman, Ismo Eriksson, Jenni Hottola, Maija Ihantola, Harri Lappalainen, Maijukka Pasanen, Eeva Putro, Jarmo Pyykkö, Vesa Salonen, and Keijo Savola. Curators of the herbaria DAOM, GB, KUO, O, OULU, PRC, PRM, SYRF, TAA, TUR, UPS are thanked for loans.

\section{References}

Berglund, H. \& Ryvarden, L. 2000: Oligoporus norrlandicus nov. sp. - Cryptogamie Mycol. 21: 145-146.

Bondartsev, A.S. 1953: Trutovye griby evropeyskoy chasti SSSR i Kavkaza. - Izdatel'stvo Akad. Nauk SSSR, Moskva \& Leningrad. 1106 pp.

Bondartseva, M.A. 1964: Novye dlya Leningradskoy oblasti vidy i formy Polyporaceae i Aporpiaceae. Novosti Sist. Nizsh. Rast. 1964: 186-195.

Bondartseva, M.A. 1998: Opredelitel' gribov Rossii. Poryadok Afilloforovye 2. - Nauka, Sankt-Peterburg. 391 pp.

Bondartseva, M.A., Krutov, V.I. \& Lositskaya, V.M. 2000: Afilloforoidnye griby osobo okhranyaemykh prirodnykh territoriy respubliki Kareliya. - In: Storozhenko, V.G. et al. (eds.), Fungal communities in forest ecosystems: 42-75. Russian Acad. Sci., Moscow \& Petrozavodsk. 321 pp.

Bondartseva, M.A., Krutov, V.I., Lositskaya, V.M. \& Svishch, L.G. 1995: Aphyllophoraceous fungi in some pine forests in eastern Finland and Russian Karelia. - In: Hokkanen, T.J. \& Ieshko, E. (eds.), Karelian Biosphere Reserve studies, North Karelian Biosphere Reserve: 195-201. North Karelian Biosphere Reserve, Joensuu. 267 pp. 
Bondartseva, M.A. \& Svishch, L.G. 1993: Afilloforovye griby probnykh ploshchadey zapovednika Kivach. - Novosti Sist. Nizsh. Rast. 29: 37-42.

Bondartseva, M.A., Zmitrovich, I.V. \& Lositskaya, V.M. 1999: Aphyllophoroid and heterobasidial macromycetes of the Leningrad Region. - In: Balashova, N.B. \& Zavarzin, A.A. (eds.), Biodiversity of the Leningrad Region: 141-173. University Press, St. Petersburg. $430 \mathrm{pp}$.

Christiansen, M.P. 1960: Danish resupinate fungi 2. Homobasidiomycetes. - Dansk Bot. Arkiv 19: 59388.

Dai, Y.C. 2000: A checklist of polypores from Northeast China. - Karstenia 40: 23-29.

David, A. 1974: Une nouvelle espèce de Polyporaceae, Tyromyces subcaesius. - Bull. Soc. Linn. Lyon 43: 119-126.

Domański, S. 1972: Fungi, Polyporaceae 1 (resupinatae), Mucronoporaceae 1 (resupinatae). - Foreign Sci. Publ. Dept. Nat. Cent. Sci. Techn. Econom. Inform., Warsaw. 235 pp., 63 tab.

Donk, M.A. 1974: Check list of European polypores. Verh. Koninkl. Nederlandse Akad. Wetensch. Afd. Natuurk. Tweede Reeks 62: 1-469.

Eriksson, J., Hjortstam, K. \& Ryvarden, L. 1984: The Corticiaceae of North Europe 7. Schizopora to Suillosporium. - Fungiflora, Oslo. Pp. 1278-1449.

Fischer, M. 2000: Porodaedalea (Phellinus pini group, Basidiomycetes) in Europe: a new species on Larix sibirica, P. niemelaei. - Karstenia 40: 43-48.

Freyndling, M.V. 1949: Materialy k flore shlyapochnykh gribov zapovednika Kivach Karelo-Finskoy SSR. - Neuvostoliiton Tiedeakat. Karjalais-Suomal. Fil. Tied. (Izvest. Karelo-Finsk. Fil. Akad. Nauk SSSR) 4: 84-97.

Hansen, L. \& Knudsen, H. 1997: Nordic Macromycetes 3. Heterobasidioid, aphyllophoroid and gastromycetoid Basidiomycetes. - Nordsvamp, Copenhagen. 444 pp.

Hermansson, J. 1997: Polyporaceae s. lat. and some other fungi in Pechoro-llych Zapovednik, Russia. Windahlia 22: 67-79.

Holec, J. \& Niemelä, T. 2000: Pholiota mucigera (Agaricales), a new species from a boreal old-growth forest. - Ann. Bot. Fennici 37: 79-83.

Jahn, H. 1973: Einige in West-Deutschland (BRD) neue, seltene oder weniger bekannte Porlinge (Polyporaceae s. lato). - Westfälische Pilzbriefe 9: 81-118.

Jahn, H. 1979: Pilze die an Holz wachsen. - Busse, Herford. $268 \mathrm{pp}$.

Karsten, P.A. 1882: Symbolae ad Mycologiam Fennicam 11. - Meddel. Soc. Fauna Flora Fennica 9: 68-71.

Kotiranta, H. \& Niemelä, T. 1996: Uhanalaiset käävät Suomessa. Threatened polypores in Finland. 2nd ed. Suomen Ympäristökeskus \& Edita, Helsinki. 184 pp.

Kotiranta, H., Uotila, P., Sulkava, S. \& Peltonen, S.L. 1998: Red Data Book of East Fennoscandia. - Ministry of Environment etc., Helsinki. 351 pp.

Kotlaba, F. 1984: Zeměpisné rozšíření a ekologie chorošů (Polyporales s.l.) y Československu. Academia, Praha. 194 pp., 123 maps.

Kotlaba, F. \& Pouzar, Z. 1991: Type studies of polypores described by A. Pilát 4. - Ceská Mykologie 45: 91-97.
Kotlaba, F. \& Vampola, P. 1993: Oligoporus folliculocystidiatus, a new polypore species allied to Oligoporus cerifluus. - Czech Mycol. 47: 59-64.

Kravchenko, A.V., Gnatiuk, E.P. \& Kuznetsov, O.L. 2000: Distribution and occurrence of vascular plants in floristic districts of Karelia. - Karelian Res. Centre, Russian Acad. Sci., Petrozavodsk. 76 pp.

Krutov, V.I. 1998: Izuchennost' gribov v lesnykh ekosistemakh Karelii. - Mycology and cryptogamic botany in Russia, traditions and modern state: 168-170. V.L. Komarov Bot. Inst., Saint Petersburg.

Kukushin, E.N. 1995: The forests of the Vodlozero National Park. - In: Kulikov, V.S. (ed.), Natural and cultural heritage of the Vodlozero National Park: 60-74. Russian Acad. Sci., Karelian Res. Cent., Petrozavodsk. [In Russian, with English summary]

Laine, L. 1979: Viljo Kujala 1891-1977 in memoriam. - Comm. Inst. For. Fenniae 92: 1-23.

Larsen, M.J. \& Lombard, F.F. 1983: Fibroporia angulopora, a new species (Aphyllophorales, Polyporaceae) associated with brown-rot of Pseudotsuga menziesii residue in western Oregon. - Mycologia 75: 623-627.

Laurila, M. 1939: Basidiomycetes novi rarioresque in Fennia collecti. - Ann. Bot. Soc. Zool.-Bot. Fennicae Vanamo 10(4): 1-24.

Lindén, H., Danilov, P.I., Gromtsev, A.N., Helle, P., Ivanter, E.V. \& Kurhinen, J. 2000: Large-scale forest corridors to connect the taiga fauna to Fennoscandia. - Wildlife Biol. 6: 179-188.

Lindgren, M. 2001: Polypore (Basidiomycetes) species richness and community structure in natural boreal forests of NW Russian Karelia and adjacent areas in Finland. - Acta Bot. Fennica 170: 1-42.

Lloyd, S. (ed.) 1999: The last of the last: the old-growth forests of boreal Europe. - Taiga Rescue Network, Intern. Coordin. Centre, Jokkmokk. 67 pp.

Lositskaya, V.M. 1997: Afilloforovye griby (poryadok Aphyllophorales) Valaamskogo arkhipelaga. - Mikol. Fitopatol. 31(6): 14-22.

Lositskaya, V.M. 1998: Afilloforovye griby Respubliki Kareliya. - In: Problemy botaniki na rubezhe XXXXI vekov, II Congr. Russian Bot. Soc., Abstracts 2: 14. Komarov Bot. Inst., Sankt-Peterburg. 359 pp.

Martikainen, P., Penttilä, R., Kotiranta, H. \& Miettinen, O. 2000: New records of Funalia trogii, Perenniporia tenuis and Polyporus pseudobetulinus from Finland, with notes on their habitat requirements and conservation implications. - Karstenia 40: 79-92.

Niemelä, T. 1981: Polypores rare in or new to Finland. - Karstenia 21: 15-20.

Niemelä, T. 1985a: On Fennoscandian polypores 9. Gelatoporia n. gen. and Tyromyces canadensis, plus notes on Skeletocutis and Antrodia. - Karstenia 25: 21-40.

Niemelä, T. 1985b: Mycoflora of Poste-de-la-Baleine, northern Quebec. Polypores and the Hymenochaetales. - Naturaliste Canadien 112: 445-472.

Niemelä, T. 1994: Suomen kääpien määritysopas. Guide to the polypores of Finland. 8th ed. - Helsingin Yliop. Kasvit. Lait. Mon. (Bot. Bull. Univ. Helsinki) 138: $1-131$.

Niemelä, T. 1998a: Steccherinum bourdotii in North Europe. - Folia Cryptog. Estonica 33: 93-97.

Niemelä, T. 1998b: The Skeletocutis subincarnata com- 
plex (Basidiomycetes), a revision. - Acta Bot. Fennica 161: 1-35.

Niemelä, T., Kotiranta, H. \& Penttilä, R. 1992: New records of rare and threatened polypores in Finland. Karstenia 32: 81-94.

Niemelä, T. \& Meike, J. 1999: CD Guide to the polypores of Finland. - CD ROM + manual, 16 pp. Finnish Museum of Natural History, Botanical Museum, Helsinki.

Noskov, G.A. (ed.) 2000: Red Data Book of nature of the Leningrad Region 2. Plants and fungi. - Governm. Leningrad Region \& Finnish Ministry Environm., St. Petersburg. 672 pp.

Olofsson, D. 1996: Tickor i Sverige. Projektrapport. Privately published, Norrköping. 127 pp.

Ovaskainen, O. (ed.) 1998: Survey of old-growth forests in Northwest Russia. - Finnish Nature League Publ. 1/ 1998: 1-105.

Overholts, L.O. 1953: The Polyporaceae of the United States, Alaska, and Canada. - University of Michigan Press, Ann Arbor. 467 pp.

Pảhlsson, L. 1995: Vegetationstyper i Norden. TemaNord 1994: 665. - Nordiska Ministerrådet, Köpenhamn. 630 pp.

Parmasto, E. 1959: Novyy vid roda Chaetoporus (sem. Polyporaceae). - Eesti NSV Tead. Akad. Toim. 8 (Biol. Ser. 2): 113-117.

Parmasto, E. 1963a: K flore gribov poluostrova Kamchatki. - Issl. Prirody Dal'nego Vostoka 1: 221-289.

Parmasto, E. 1963b: K mikologicheskoy flore Komi ASSR. - Tartu Riikliku Ülikooli Toim. 136: 103-129.

Pilát, A. (ed.) 1948: Velenovskýi species novae Basidiomycetum. - Opera Bot. Čechica 6: 1-319.

Popova, T.A. \& Noskov, G.A. 1999: Vepsskiy les. - In: Red Data Book of nature of the Leningrad Region 1. Protected areas: 60-61. Governm. Leningrad Region \& Finnish Ministry Environm., St. Petersburg. 350 pp.

Pouzar, Z. 1967: Studies in the taxonomy of the polypores 3. - Česká Mykologie 21: 205-212.

Pyykkö, J. (ed.) 1996: Survey in Russian Karelian natural forests in Vienansalo. - WWF Finland, Helsinki. $41 \mathrm{pp}$.

Quanten, E. 1997: The polypores (Polyporaceae s.1.) of Papua New Guinea. A preliminary conspectus. - Opera Bot. Belgica 11: 1-352.

Renvall, P. 1995: Community structure and dynamics of wood-rotting Basidiomycetes on decomposing conifer trunks in northern Finland. - Karstenia 35: 1-51.

Renvall, P. \& Junninen, K. 1999: Rigidoporus crocatus re-collected in Finland, plus new records of other rare polypores (Basidiomycetes). - Karstenia 39: 33-35.

Ryvarden, L. \& Gilbertson, R.L. 1993: European polypores 1. Abortiporus to Lindtneria. - Synopsis Fungorum 6: $1-387$.

Ryvarden, L. \& Gilbertson, R.L. 1994: European polypores 2. Meripilus to Tyromyces. - Synopsis Fungorum 7: 388-743.

Shubin, V.I. \& Krutov, V.I. 1979: Griby Karelii i Murmanskoy oblasti. - Nauka, Leningrad. 104 pp.

Siitonen, J. \& Martikainen, P. 1994: Occurrence of rare and threatened insects living on decaying Populus tremula, a comparison between Finnish and Russian Karelia. - Scandinavian J. For. Res. 9: 185-191.
Siitonen, J., Penttilä, R. \& Kotiranta, H. 2001: Coarse woody debris, polyporous fungi and saproxylic insects in an old-growth spruce forest in Vodlozero National Park, Russian Karelia. - Ecological Bull. 49 (in press).

Strandberg, M. \& Strandberg, B. 1991: Pycnoporellus fulgens, en ny dansk poresvamp. - Svampe 24: 1517.

Thesleff, A. 1920: Studier öfver basidsvampfloran i sydöstra Finland. - Bidr. Känned. Finlands Natur Folk 79(1): 1-140.

Tortić, M. 1974: New European records of Tyromyces kmetii and Pycnoporellus alboluteus (Polyporaceae) and the identity of Irpex woronowii Bres. - Česká Mykologie 28: 26-34.

Vampola, P. 1992: Severoamerický choroš Fibroporia radiculosa (pórnatka sírožlutá) nalezen v Československu. - Česká Mykol. 46: 223-227.

Vampola, P. 1994: Poznámky ke komplexu bělochoroše modravého - Postia caesia. - Mykol. Listy (Praha) 52: 5-7.

Velenovský, J. 1920-1922: České houby 1-5. - České Botanické Společnosti, Praha. 950 pp.

Zmitrovich, I.V. 1999a: Griby Nizhnesvirskogo zapovednika 3. Makromitsety (Heterobasidiomycetes, Aphyllophorales 1). - Rossiyskaya Akad. Nauk, Sankt-Peterburg. 66 pp.

Zmitrovich, I.V. 1999b: Kortitsioidnye i geterobazidial'nye makromitsety Leningradskoy oblasti. Novosti Sist. Nizsh. Rast. 33: 65-79. 